\title{
Hospital accreditation methods in Iran: Challenges and solutions
}

\author{
Ali Mohammad Mosadeghrad ${ }^{1}$, Ebrahim Jaafaripooyan ${ }^{1}$, Fatemeh Ghazanfari ${ }^{1 *}$ \\ 1. School of Public Health, Tehran University of Medical Sciences, Tehran, Iran
}

Received: 5 November 2020

Accepted for publication: 2 November 2021

[EPub a head of print-6 November 2021]

Payesh: 2021; 20 (6): 655- 670

\begin{abstract}
Objective (s): Hospital accreditation is "an external evaluation of a hospital by an independent professional accreditation body using pre-established optimal structural, process and outcome standards". The Iranian hospital accreditation program faces some challenges. This study aimed to identify the Iranian hospital accreditation method challenges and provide suggestions for their improvement.

Methods: This qualitative study was performed using semi-structured interviews in 2019. Using a pluralistic evaluation approach, 151 policy makers, managers and employees, accreditation surveyors, and academics from ministry of health, medical universities, hospitals and health insurance companies were purposively recruited and interviewed. Thematic analysis was used for data analysis.

Results: Overall, 27 challenges and 17 solutions were identified and grouped into five categories including accreditation time, accreditation method, accreditation duration, accreditation feedback, and accreditation certificate. Giving insufficient time to hospitals to implement accreditation standards, different evaluation methods of evaluators, inefficiency of self-assessment and periodic evaluation, failure to provide detailed feedback to hospitals, lack of supporting hospitals, and a lack of public announcement of results were the main challenges. Some solutions for overcoming these challenges were as setting a specific time frame for accreditation, using a scientific and patient-centered method for evaluation, improving surveyors' knowledge and skills, independence of the accreditation organization, providing detailed feedback to hospitals, determining a two-year validity for accreditation certificate and public announcement of hospitals' accreditation results.

Conclusion: Iran's hospital accreditation method faces several challenges. Improving the accreditation evaluation method can increase the credibility and reliability of Iranian hospital accreditation results.
\end{abstract}

Key words: Hospital Accreditation, Methods, challenges, solution

\footnotetext{
${ }^{*}$ Corresponding author: School of Public Health, Tehran University of Medical Sciences, Tehran, Iran

E-mail:maha5065@yahoo.com
} 


\section{روش ارزشيابى اعتباربخشى بيمار ستانى ايران: جالشها و راهكارها}

على محمد مصدق راد'، ابراهيم جعفرى پويان ؛ فاطمه غضنفرى ا* 1. دانشكده بهداشت، دانشعاه علوم يزشكى تهران، تهران، ايران

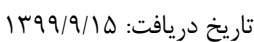

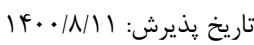

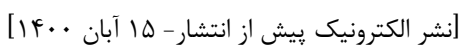

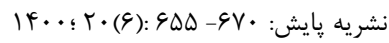

جكيده مقدمه: اعتباربخشى بيمارستانى "فرايند ارزشيابى نظام مند و تعيين اعتبار بيمارستان توسط يك سـازمان مسـتقل حرفـهاى بـا اسـتفاده از اسـتانداردهاى

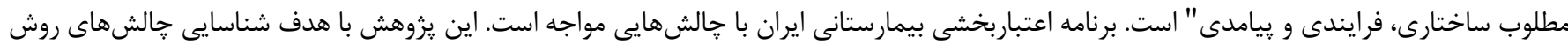

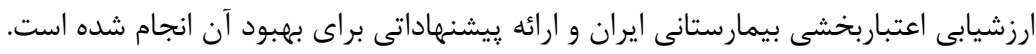

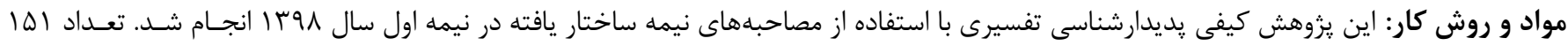

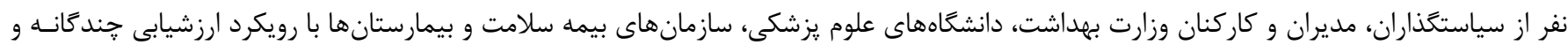

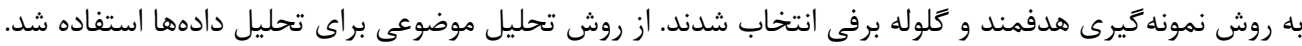

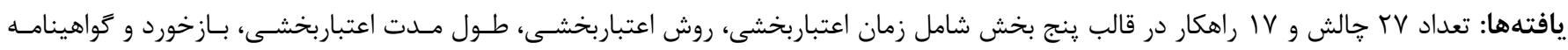

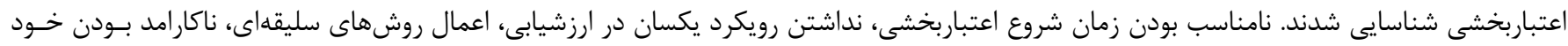

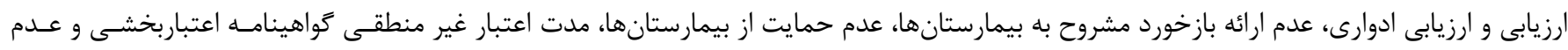

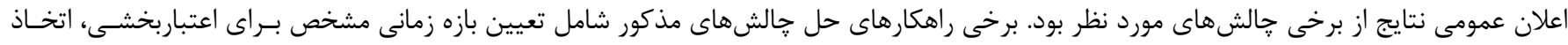

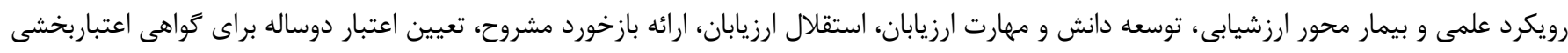
و اعلان عمومى نتايج بود.

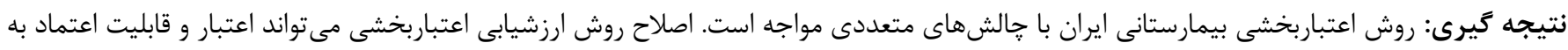

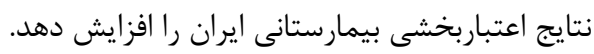

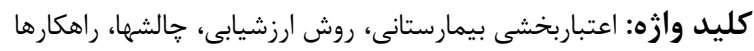




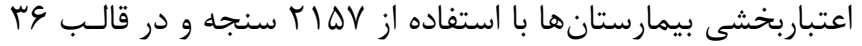

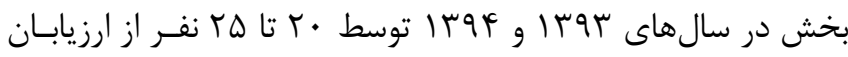

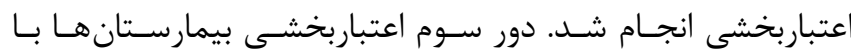

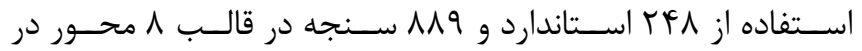

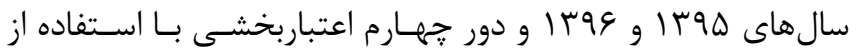

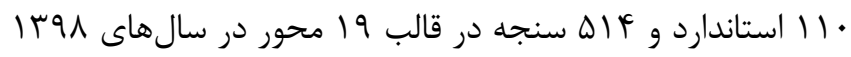

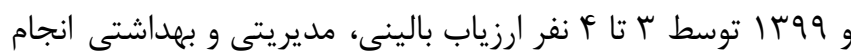

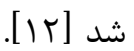
روش ارزشيابى برنامـهـ اعتباربخشى بيمارسـتانهـاى ايـران شـامل

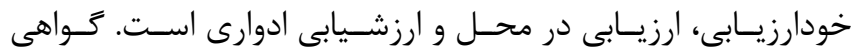

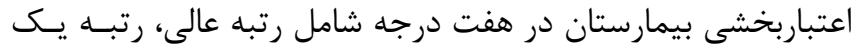

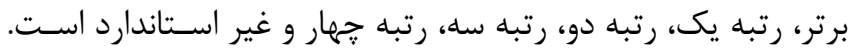

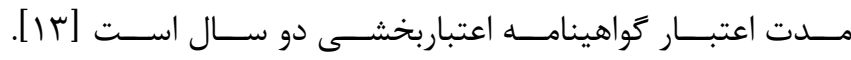

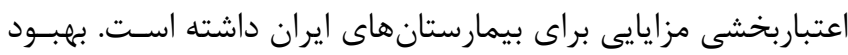

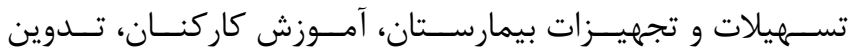

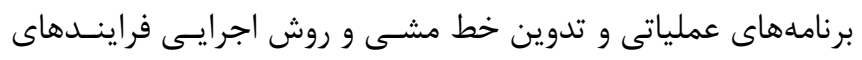

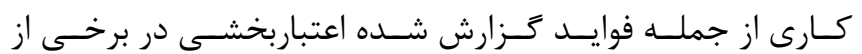

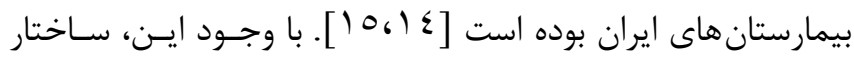

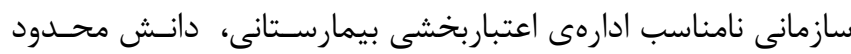

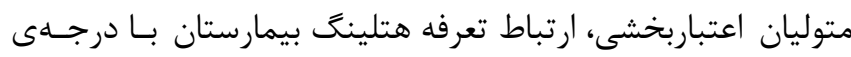

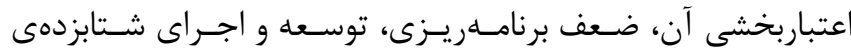

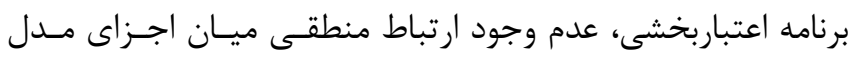

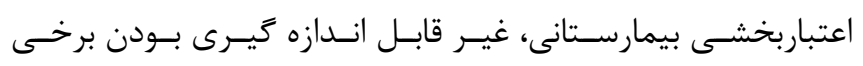

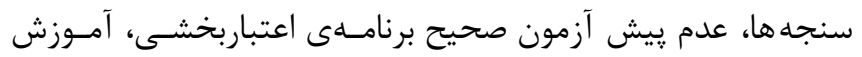

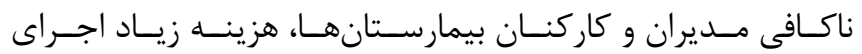

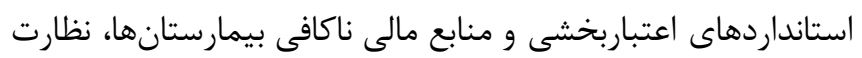

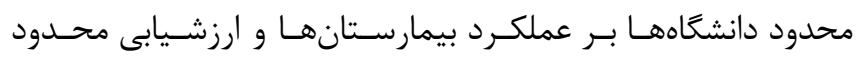

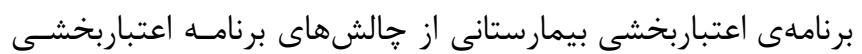

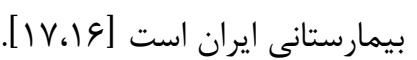

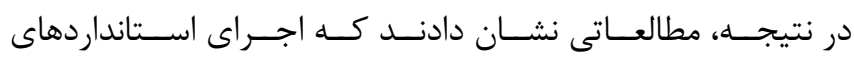

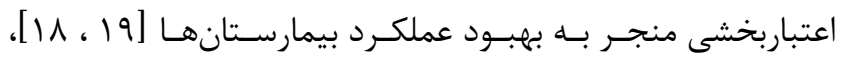

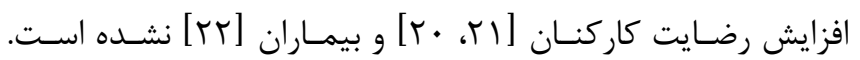

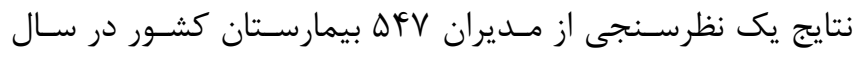

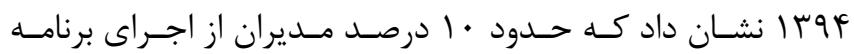

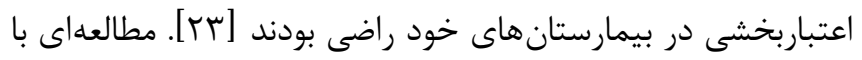

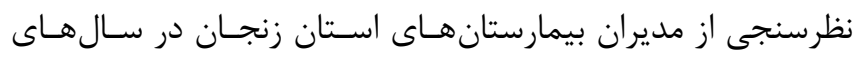

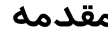

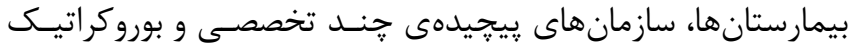

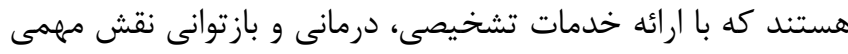

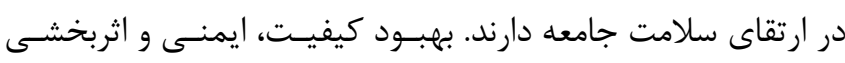

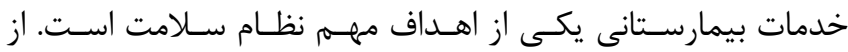

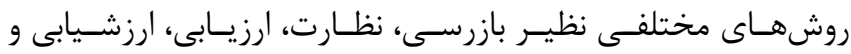

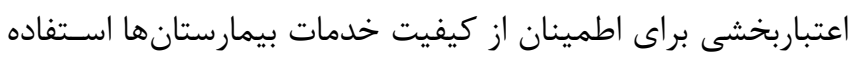

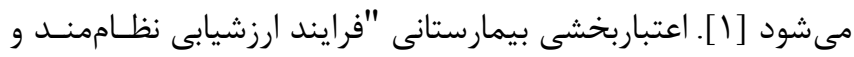

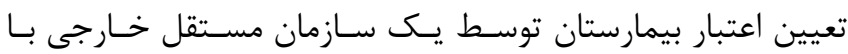

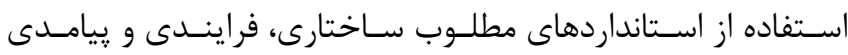

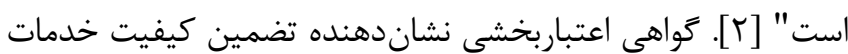
بيمارستان بوده و معيارى براى انتخاب بيمارستان توسط بيمار براى

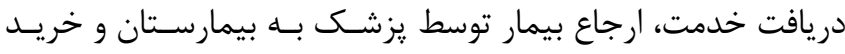

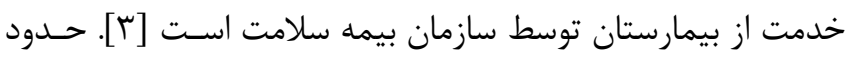

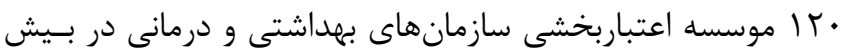

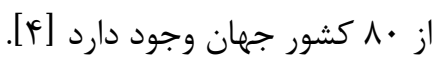

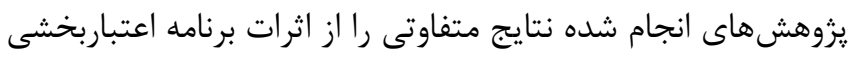

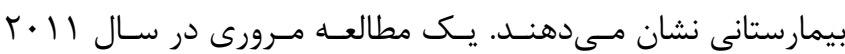

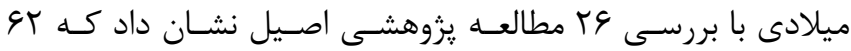

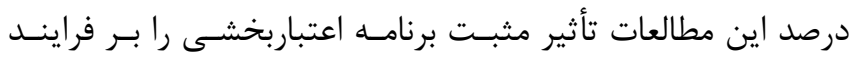

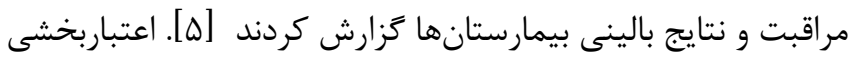

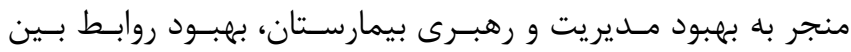

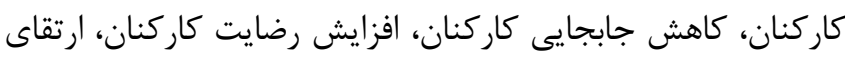

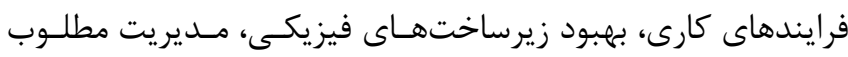

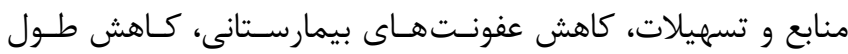
مدت اقامت بيمار در بيمارستان، كاهش مــرى و ميـر بيمارسـتانى

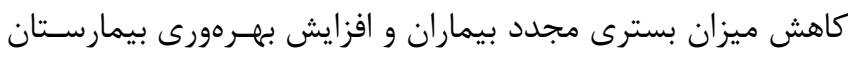

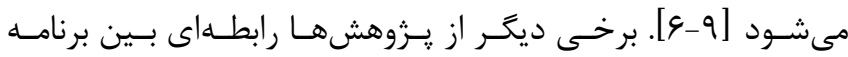

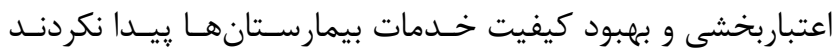
[111.1.]

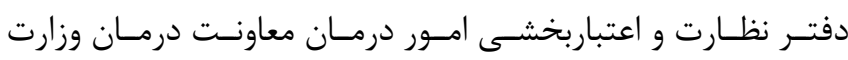

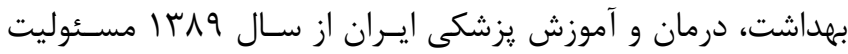

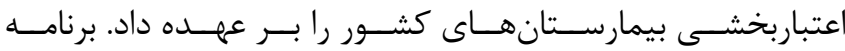

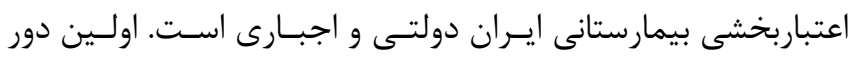

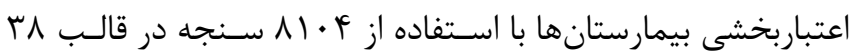

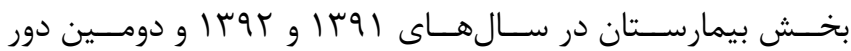




\section{مواد و روش كار} اين يزوهش كيفى با روش :بديدارشناسى Phenomenology در نيمه

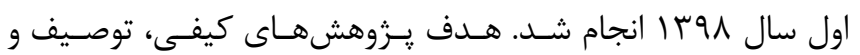

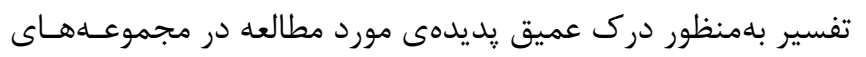

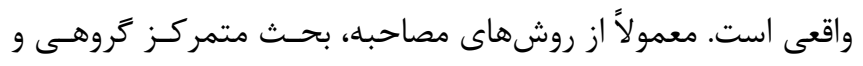
مشاهده براى انجام يزوهشى :ماى كيفى استفاده مىشود. يزوهشهاى كيفى در :جهل سال گذشته در علوم اجتماعى و به ويزه در مطالعات

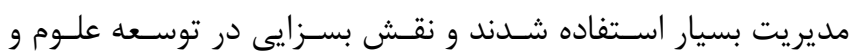

فناورى مربوطه داشتند [بهـ]

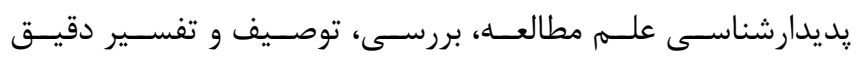

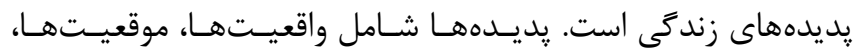

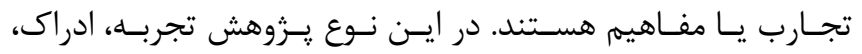

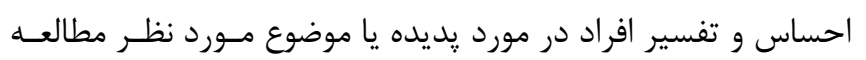

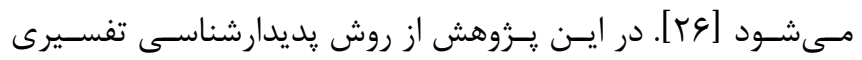
Interpretive phenomenology تفسير جالش هاى روش ارزشيابى اعتباربخشى بيمارسـتانى ايـران و

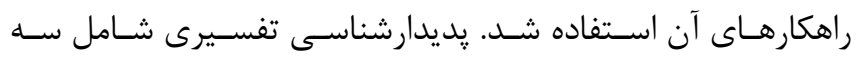

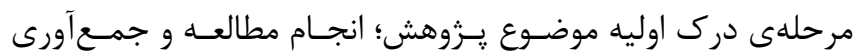
اطلاعات؛ و تأمل و تفكر روى دادهها است [rv] موريه.

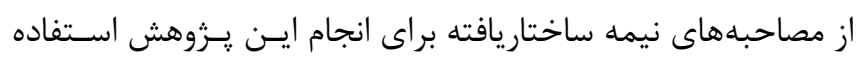

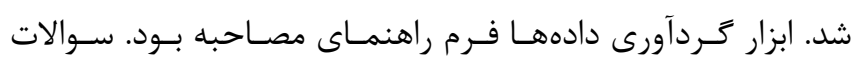

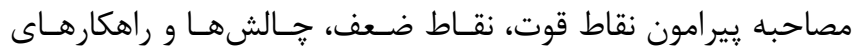
بهبود روش اعتباربخشى بيمارستانى ايران بود. تعـداد • ا مصـاحبه

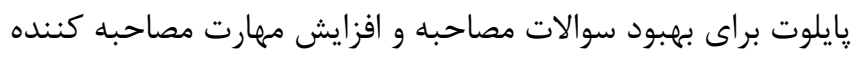

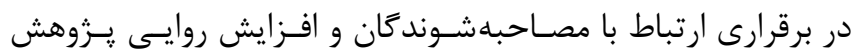

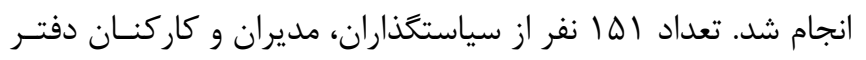

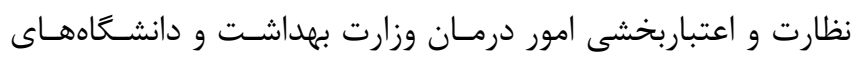

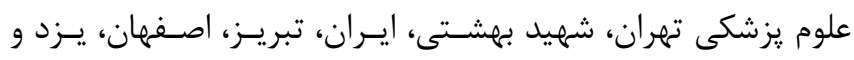

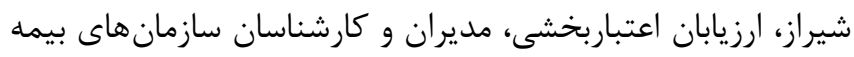

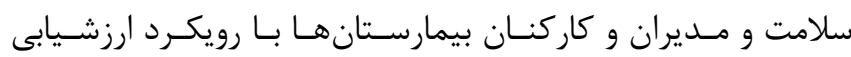
جندگًانه Pluralistic evaluation و به روش نمونه كلوله برفى انتخاب و در اين يزوهش شركت نمودند. مصـاحبههـا در

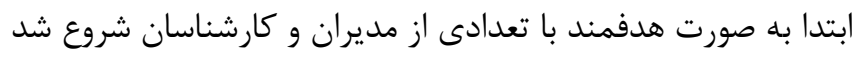

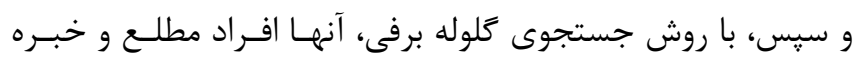

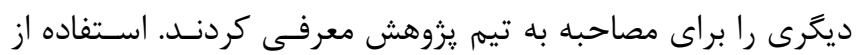

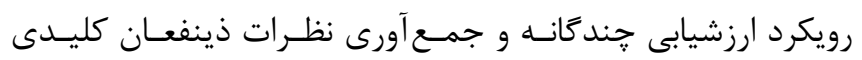

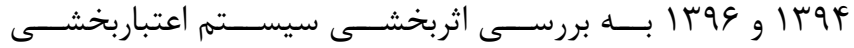

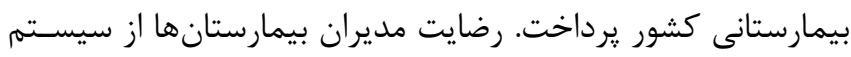

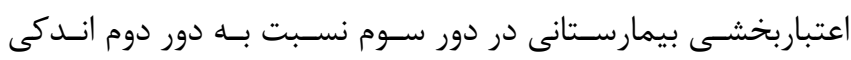

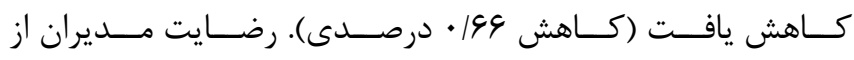

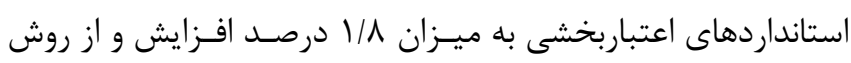
اعتباربخشى و اجراى استانداردهاى اعتباربخشى در بيمارستانها بـانها به

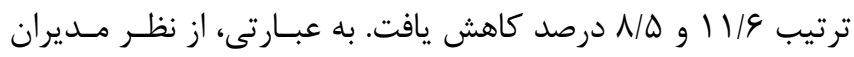
بيمارستان ها تغيير سيستم اعتباربخشى بيمارستانى ايـران در سـال

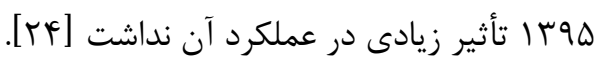

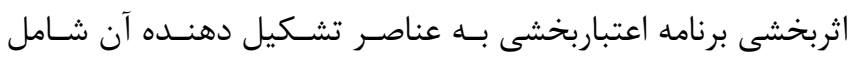

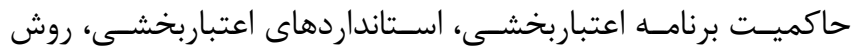

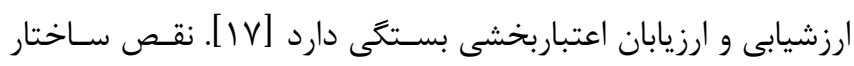

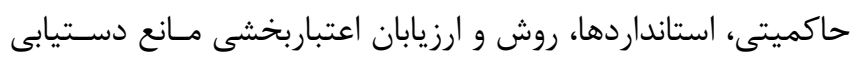

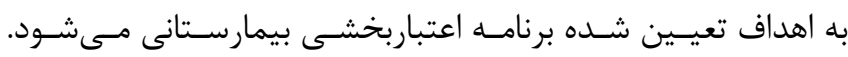

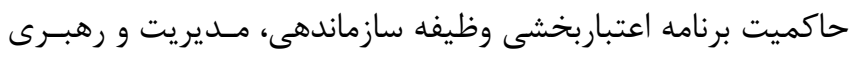

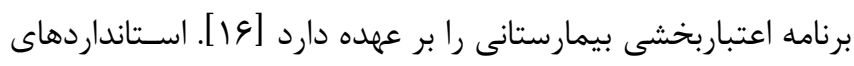
اعتباربخشى بايد بر مبناى اصول بهبود كيفيت، ايمنى، اثربخشىى و

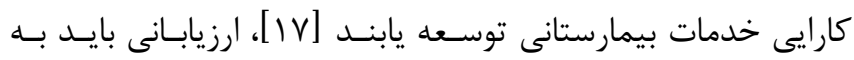

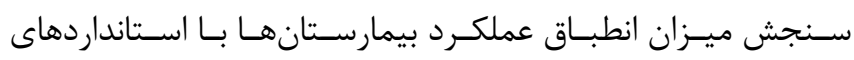

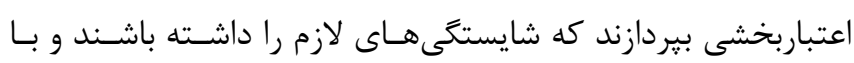
اسـتفاده از رويكـرد سيسـتمى بــه ارزشـيابى ســاختارها، بافتارهــا،

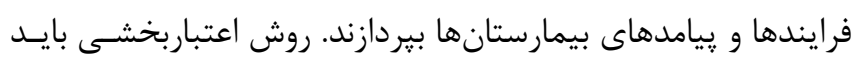

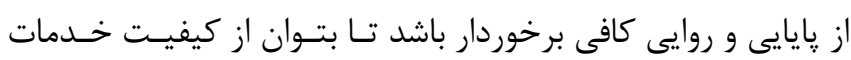
ارائه شده در بيمارستان ها اطمينان حاصل نمود. روش ارزشيابى اعتباربخشى مى تواند اعتبار و قابليت اعتماد به نتايج

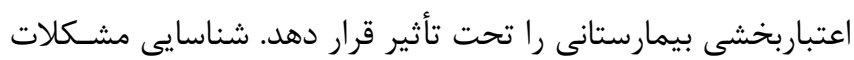

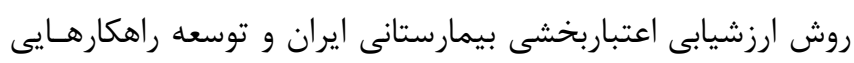

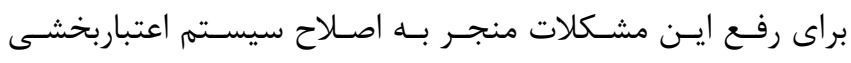

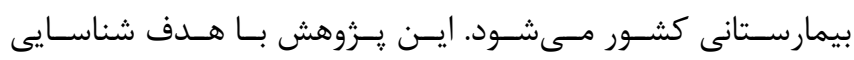

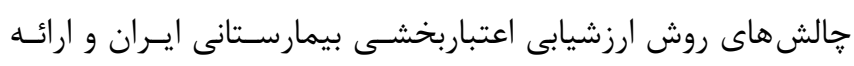

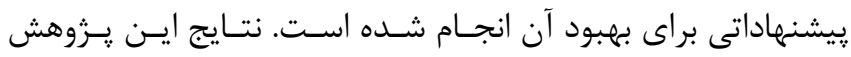

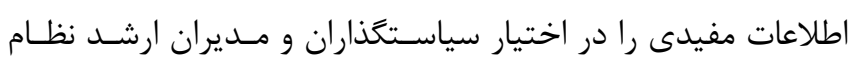

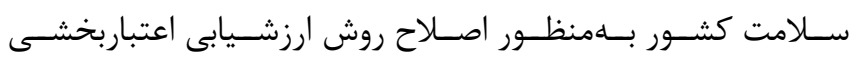
بيمارستانى قرار مىدهد. 
يافتهها تعداد VV جالش روش اعتباربخشى بيمارستانى ايران و IV راهكار

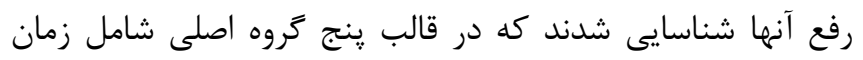

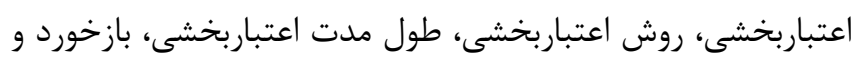

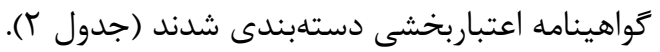

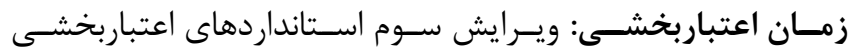

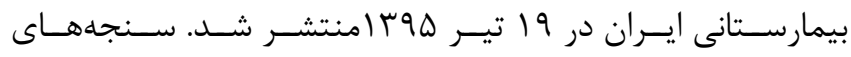

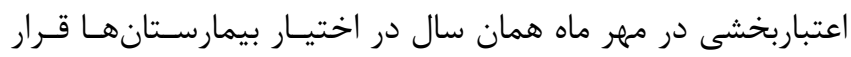

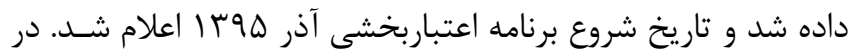

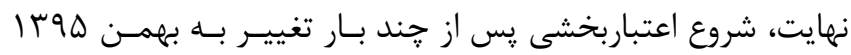

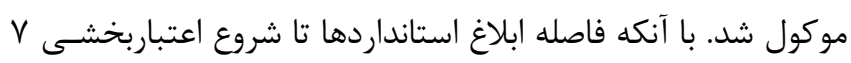

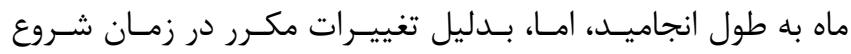

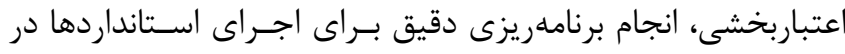

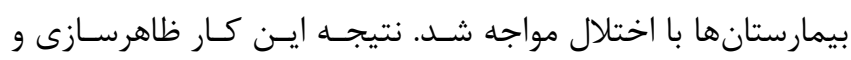

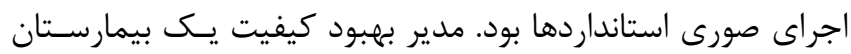

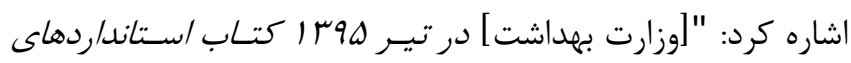

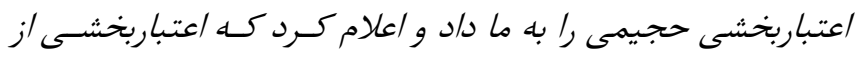

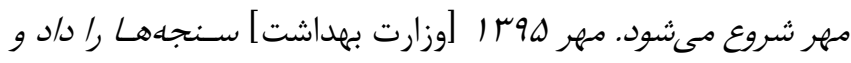

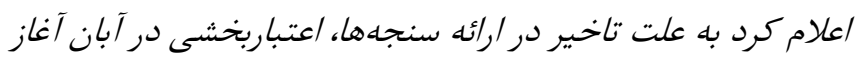

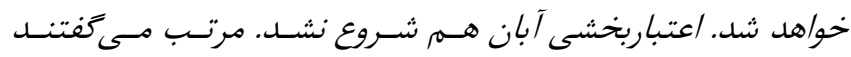

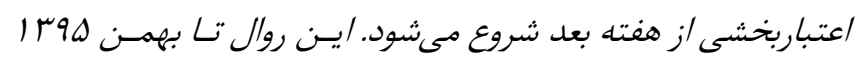

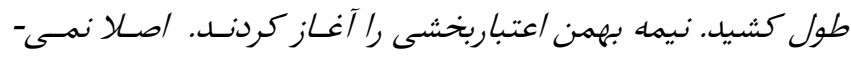

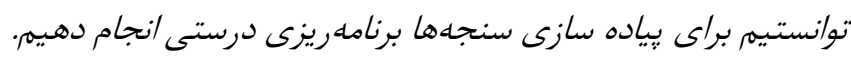

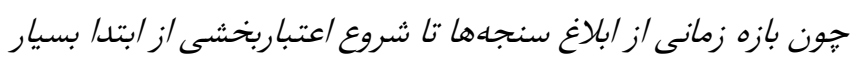

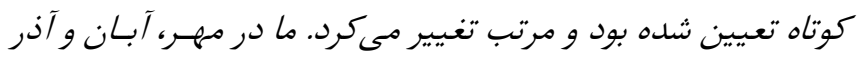

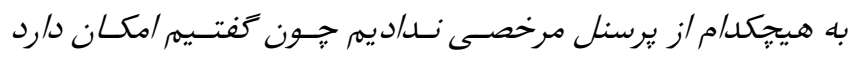

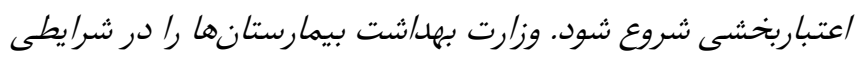

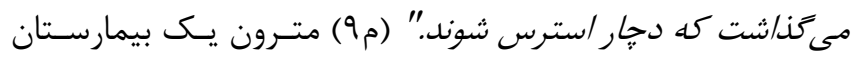

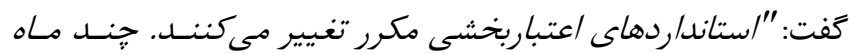

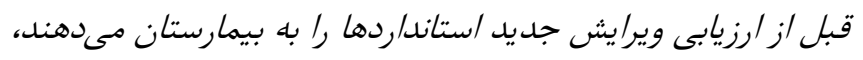

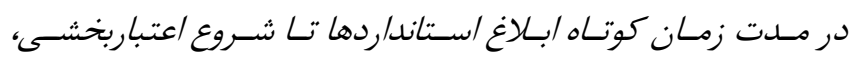

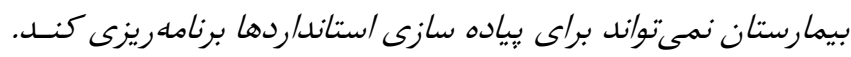

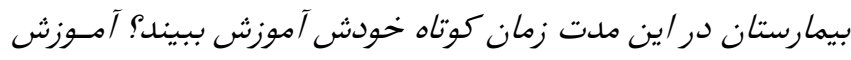

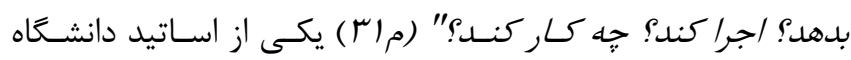

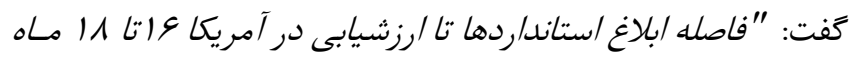

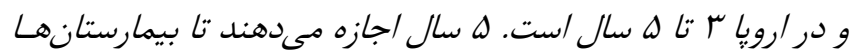

متعدد، منجر به دستيابى به اطلاعات جامع و معتبــرى شـد كـه در

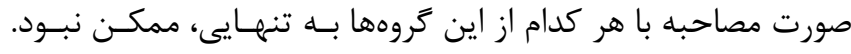

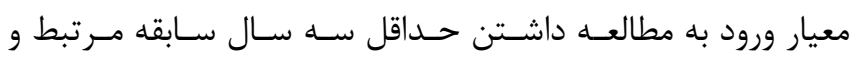

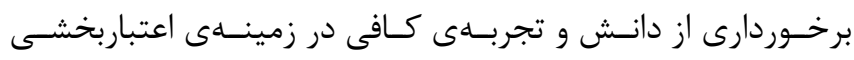

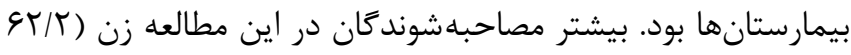

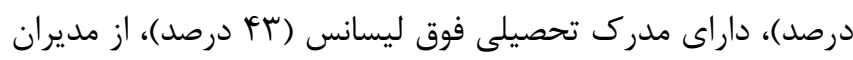

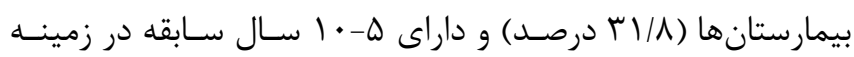

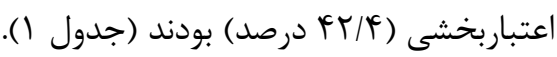

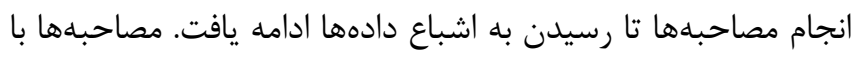

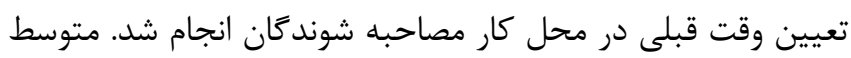

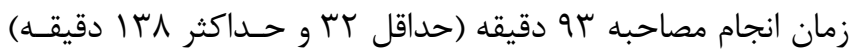

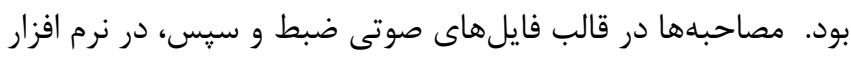
Word از روش تحليل موضوعى 9 مرحلهاى براون و كلاركى شامل آشـنايى با دادهها، شناسايى كدهاى اوليـه، جسـتجوى درون مايـهـهـا، مـرور

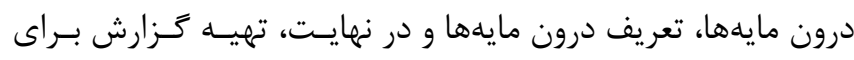

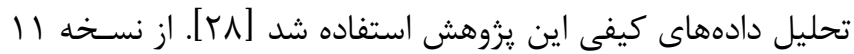

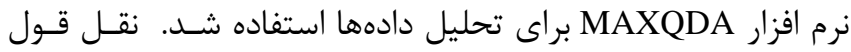
مصاحبه شوندكان با حرف "م" در اين مقاله مشخص شده است.

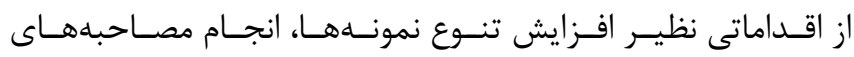

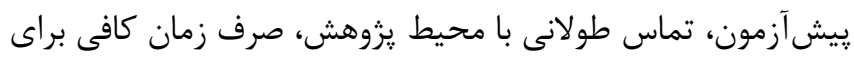

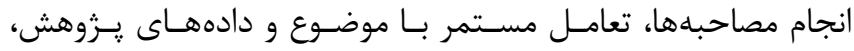

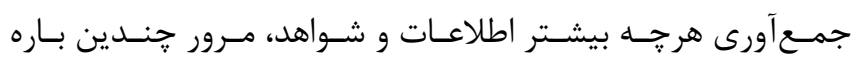
مصاحبهها، مقايسه مستمر اطلاعات بدست آمـده، ارسـال يافتـهـــا

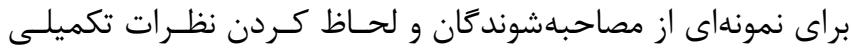

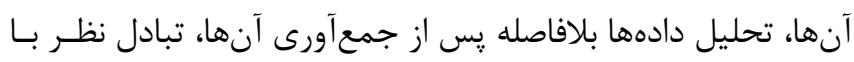

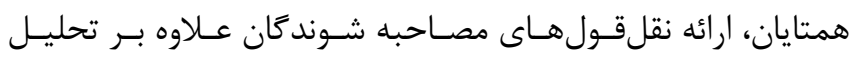

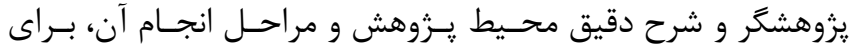

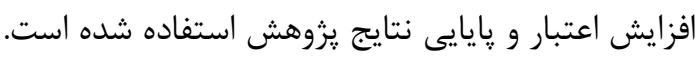

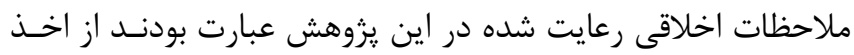

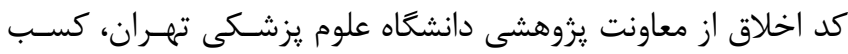

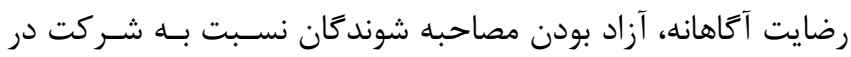

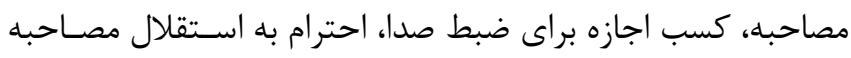

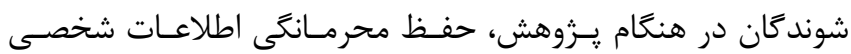

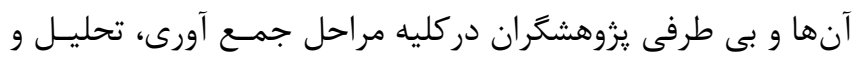
كزارش دادهها. 
در مناطق كوهستانى و صعب العبور دشوار بود. يكسى از ارزيابـان در

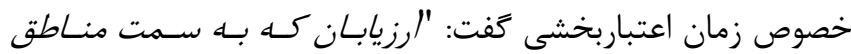

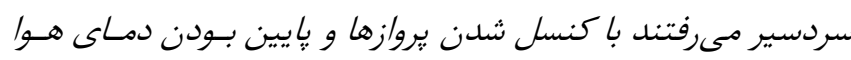

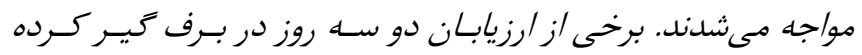

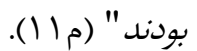

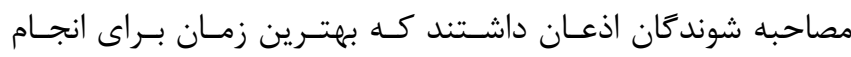

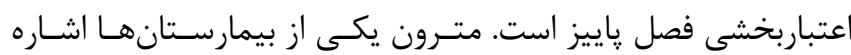

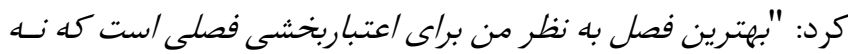

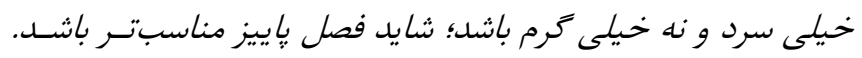

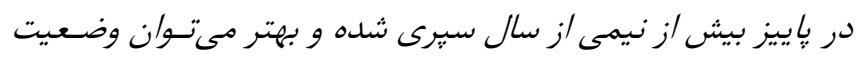

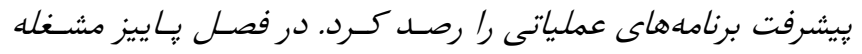

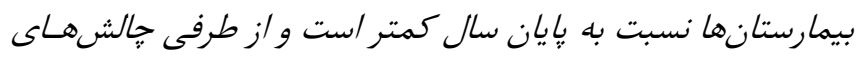
مختص ابتداى سال هم وجود ندارد" (مع • ()).

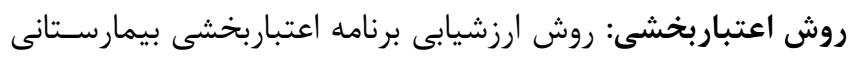

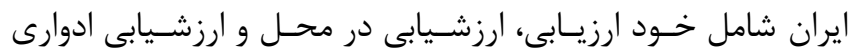

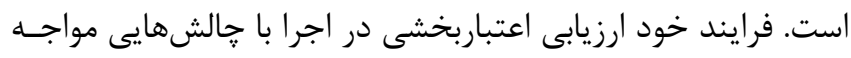

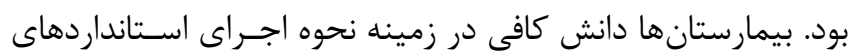

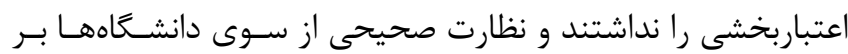

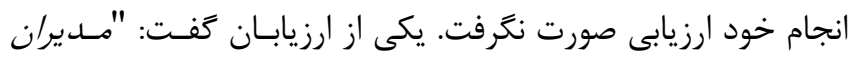

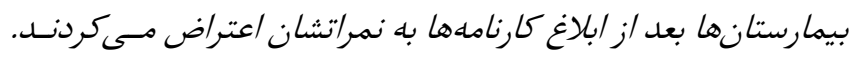
بعد /ز بررسى توسط وزارت بهد/شت مشخص مى بشد كه بيمارستان

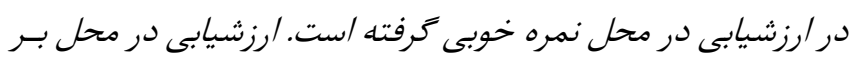

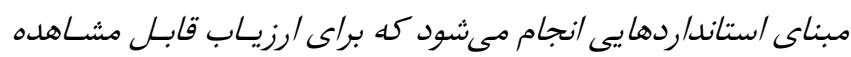

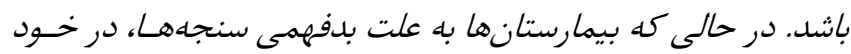

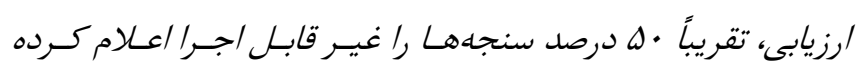

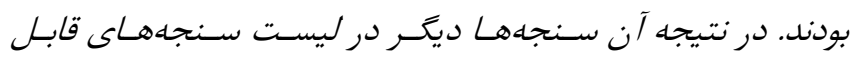

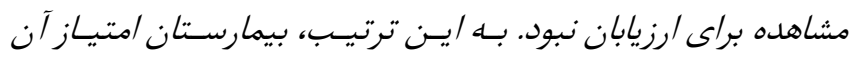

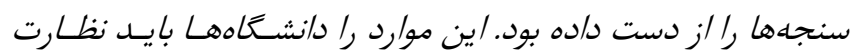

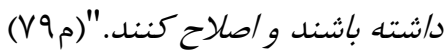

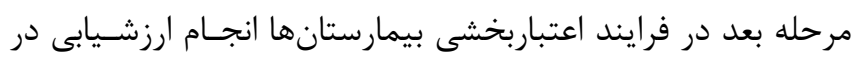
محل است كه قرار بود بـهـ روش مصـاحبه بـا كار كنـان و ذينفعـان، مشاهده عملكردها و زيرساختها و بررسى مستندات انجام شود. امـا

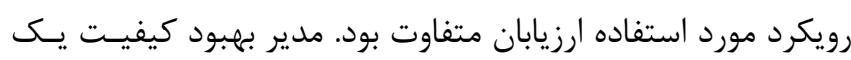

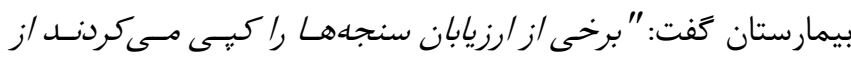

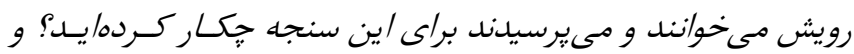

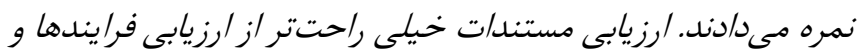

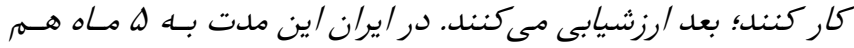

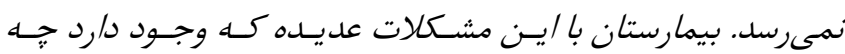

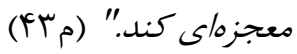
مصاحبه شوندكان بيشنهاد دادند كه حداقل زمان مـورد نيـاز بـراى

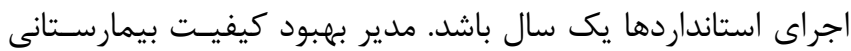

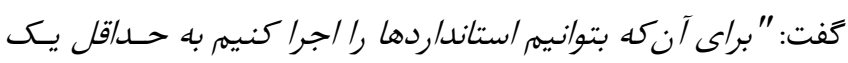

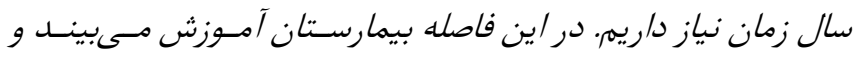

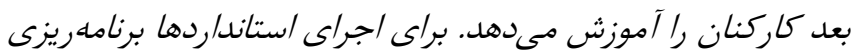

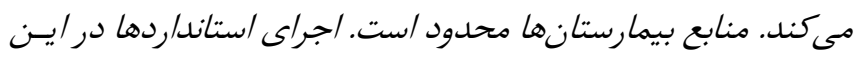

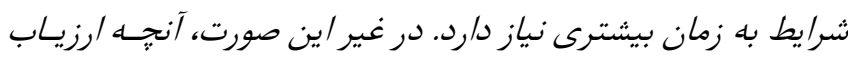

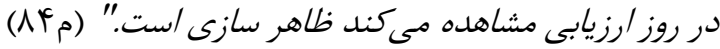

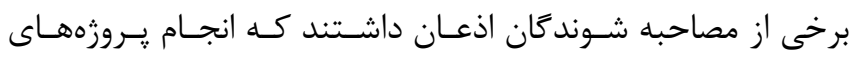

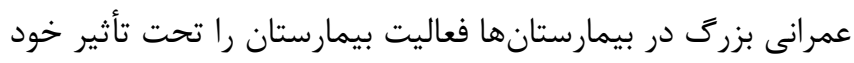

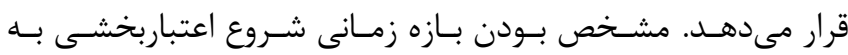

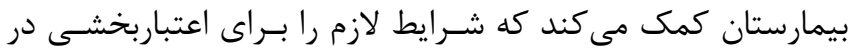

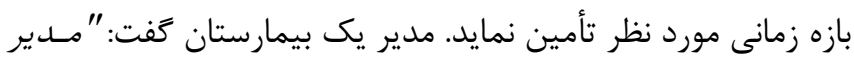

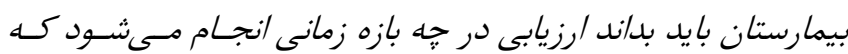

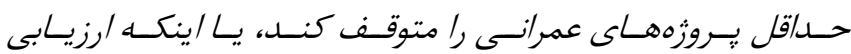

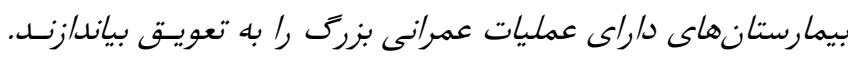

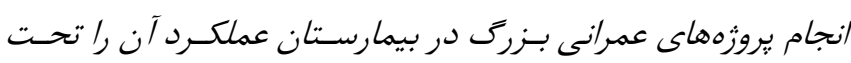

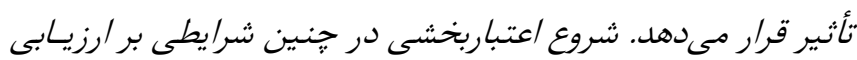

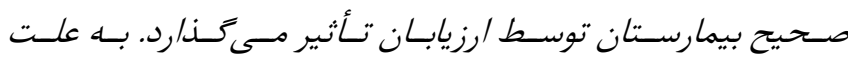

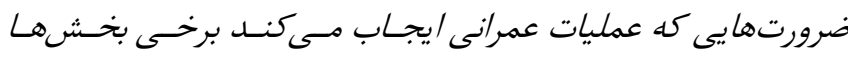

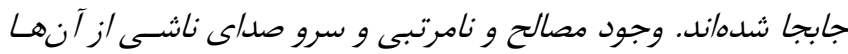

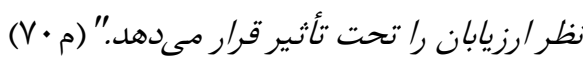

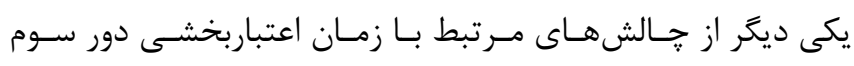

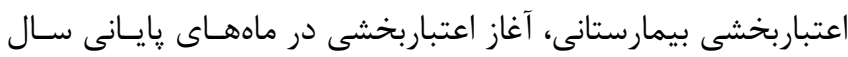

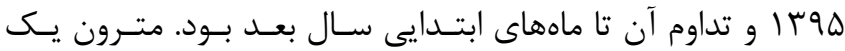

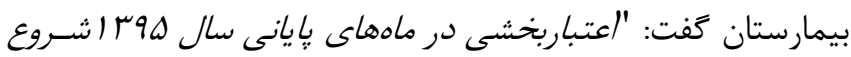

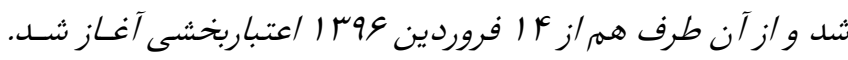

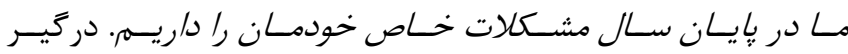

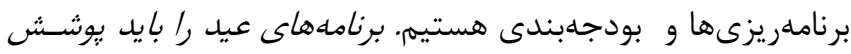

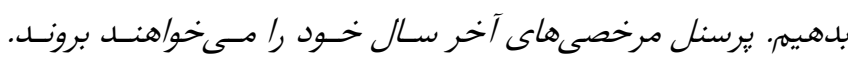

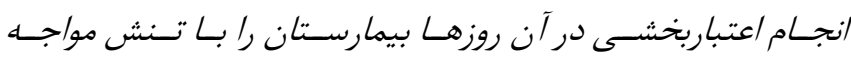

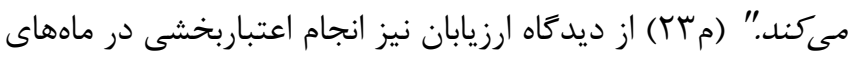

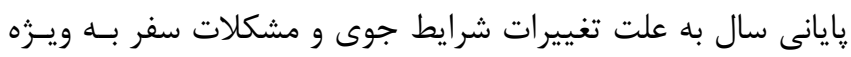


دانشكاه كفت: "/ينكه وزارت بهد/شـت يكس دوره سـه روزه آمـوزش

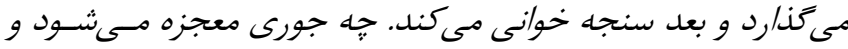

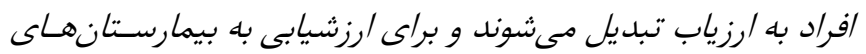
بزركى مثل /مام يا شريعتى اعزام مىشوند." (م • (1)

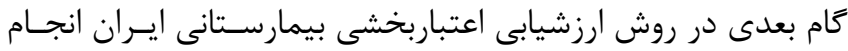

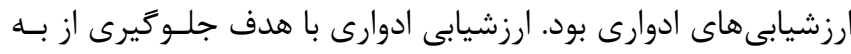

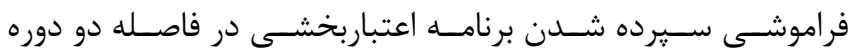
اعتباربخشى ايجاد شد. ارزشيابى ادوارى با خالشهايى مواجـهـ بـود.

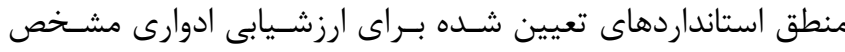

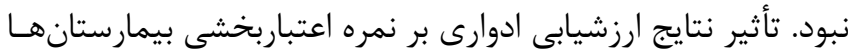

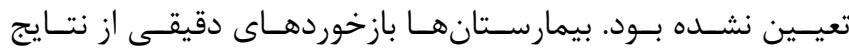

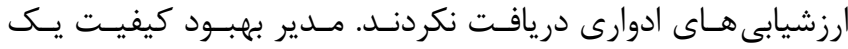

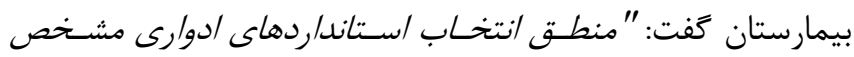

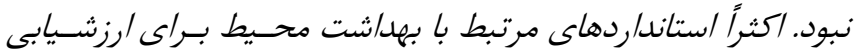

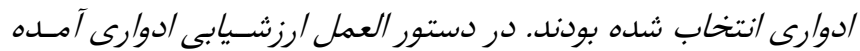

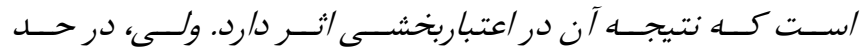

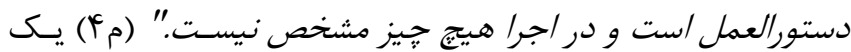

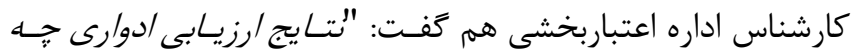

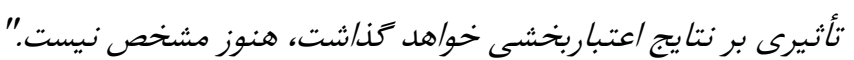

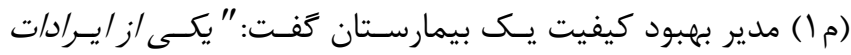

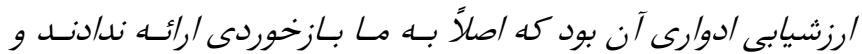

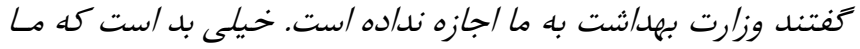

نقاط قوت و ضعف عملكردمان رانمى بدانيم." (م • 9.

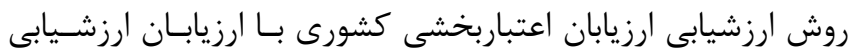

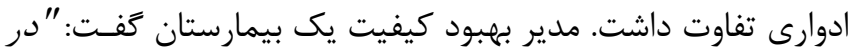

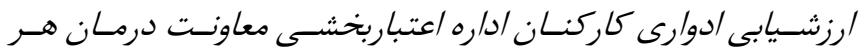

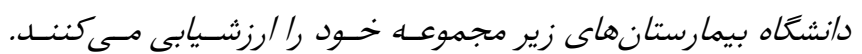

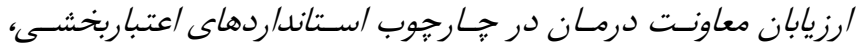

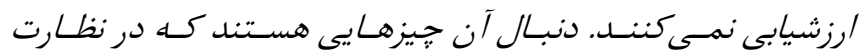

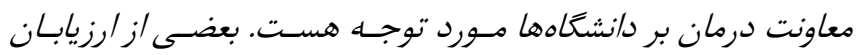

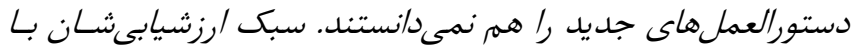

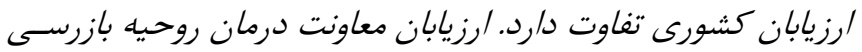

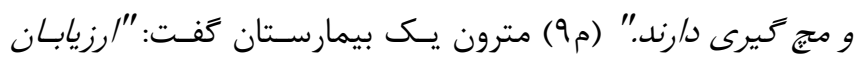

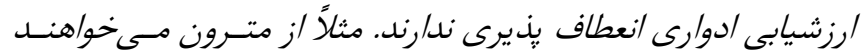

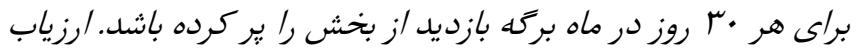

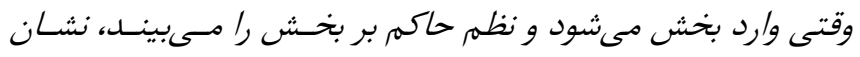

يامدها /ست. بنابراين، /رزيابان كم تجربه بيشتر بـر روى مستندات

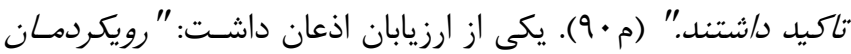

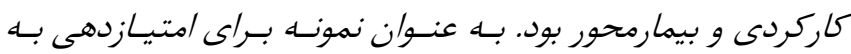

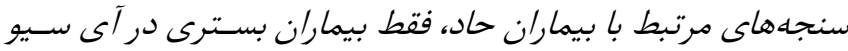

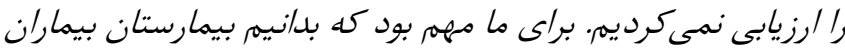

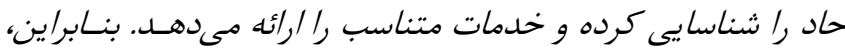

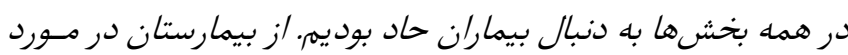

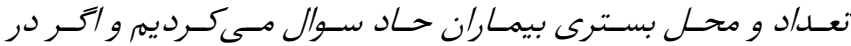
ارزيابیها مورد ديكرى خارج از اطلاع بيمارستان مىيـافتيمه، امتياز

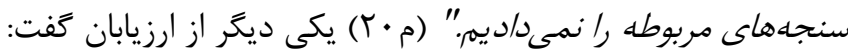

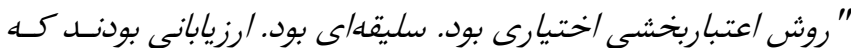

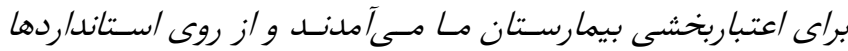

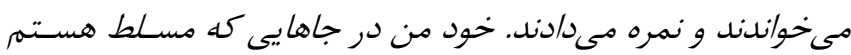
با يكى نكاه مىتوانم تعداد زيادى سنجه را امتياز دهى كنهم، ولسى، در

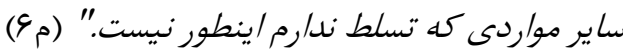

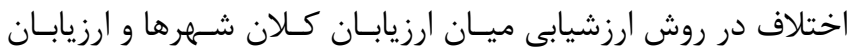

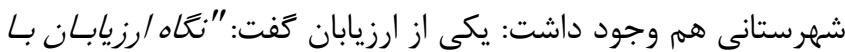

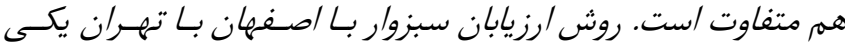

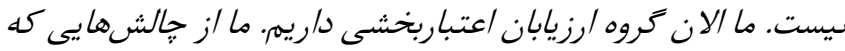

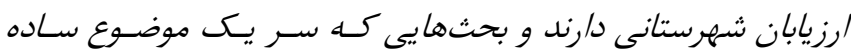

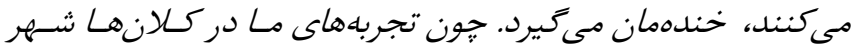

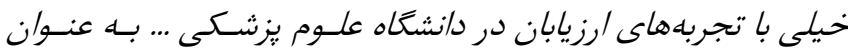

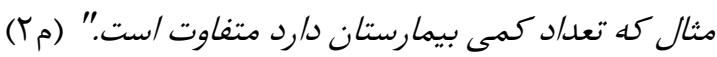

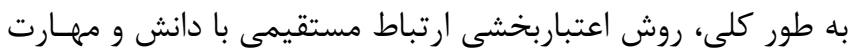

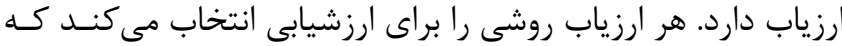

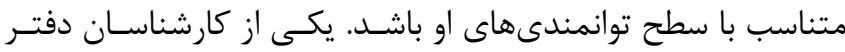
اعتباربخشى وزارت بهداشت كَفت: "دوره آمسوزش ارزيابـان كوتساه و

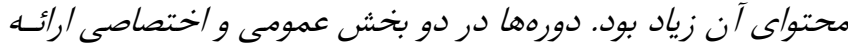

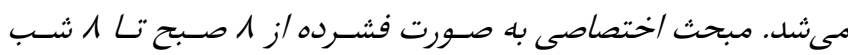

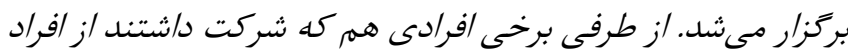

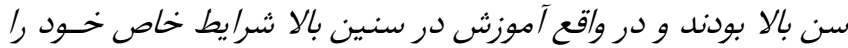

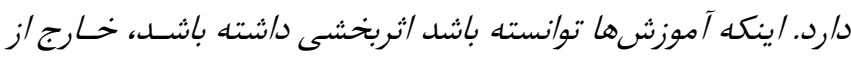

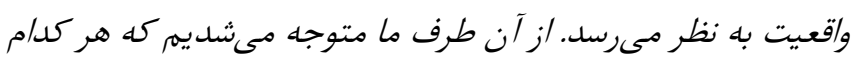

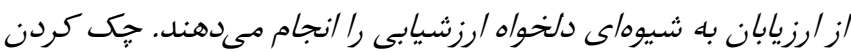

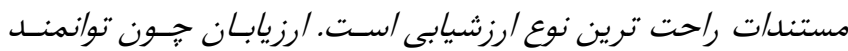

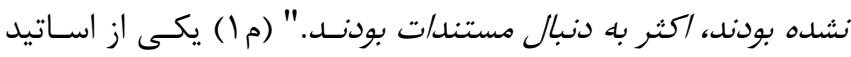


است. يك شاخص به من بَّو كه /رتقا يافته. / ين در حالى /سـت كسه

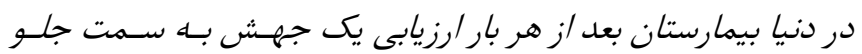

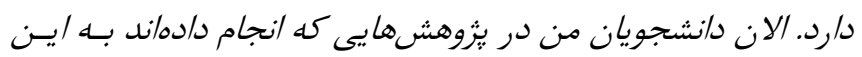

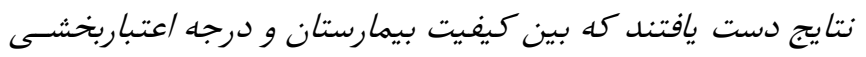

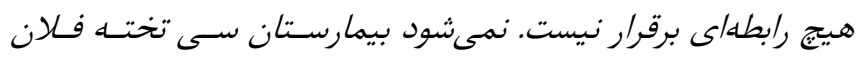

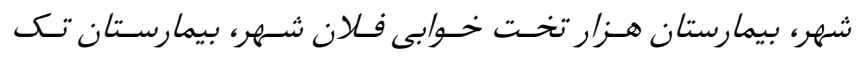

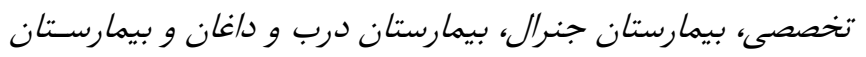

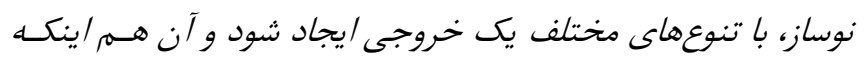

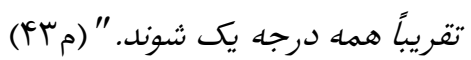

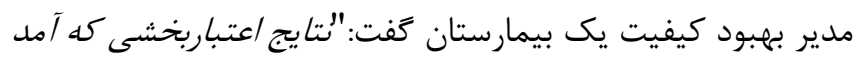

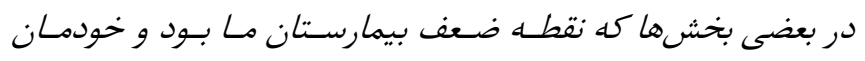

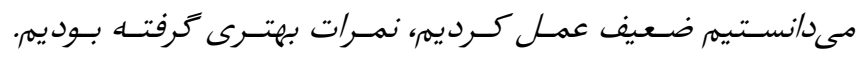

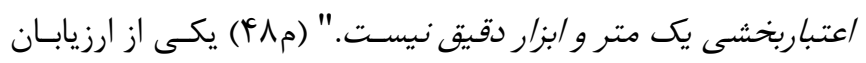

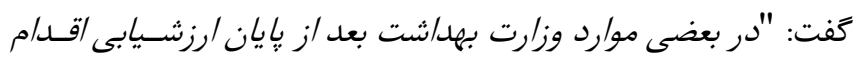

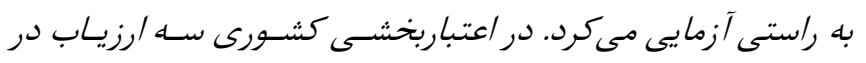

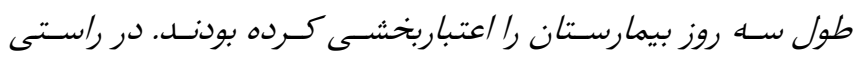

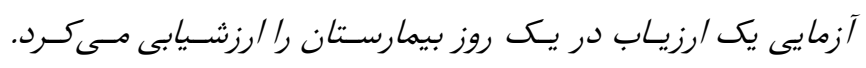

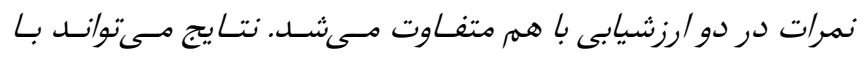

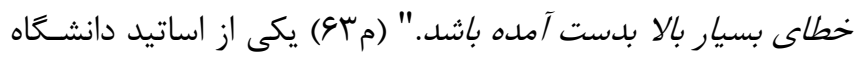

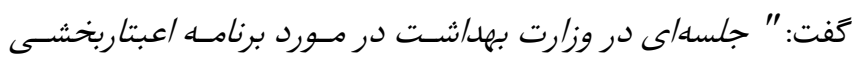

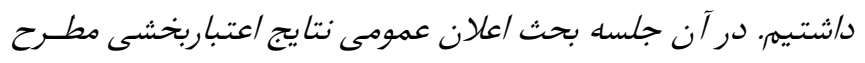

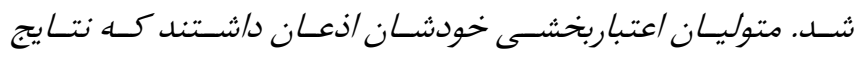

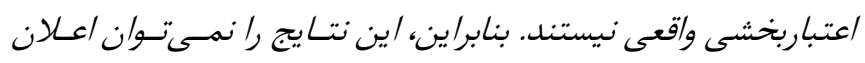

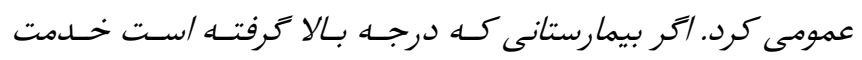

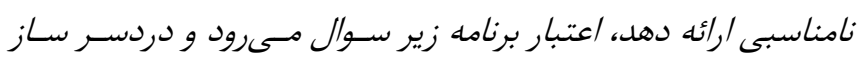

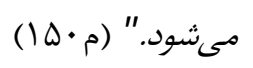

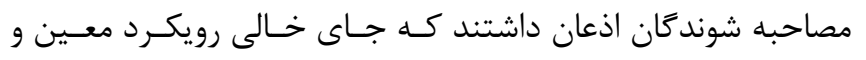

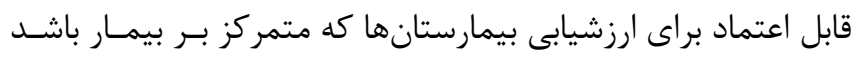

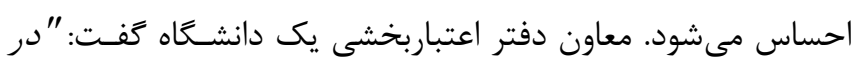

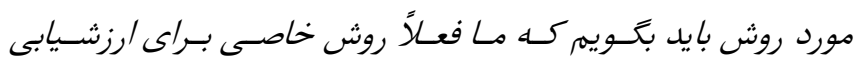

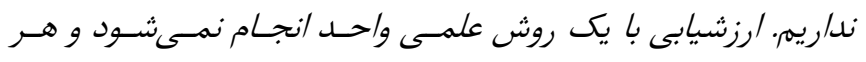

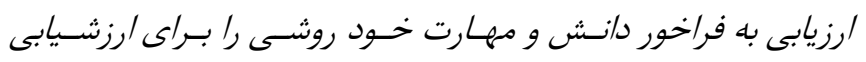

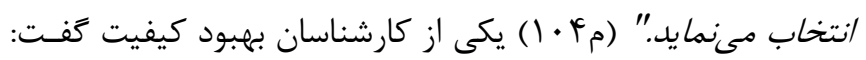

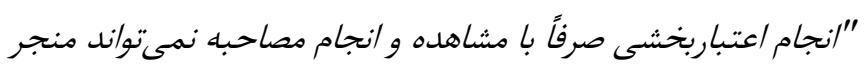

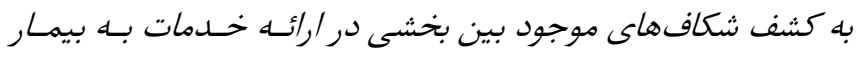

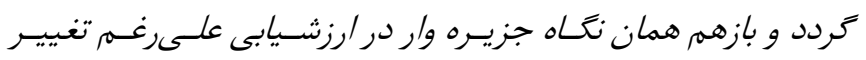

دهنده / ين /ست كه بازديدها به موقع انجـام شــه /سـت آنهـا بـهـ

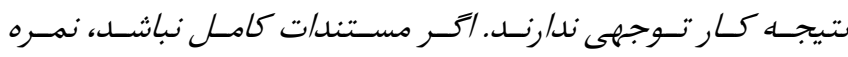

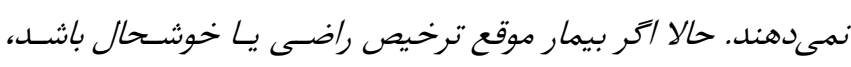

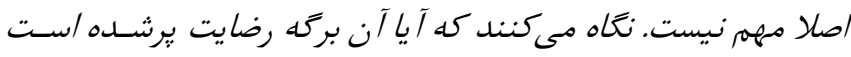

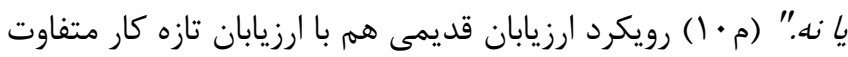

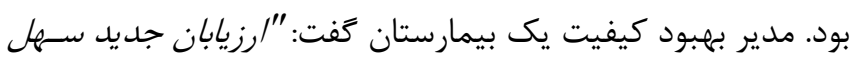

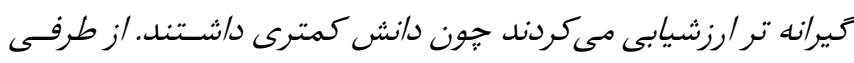

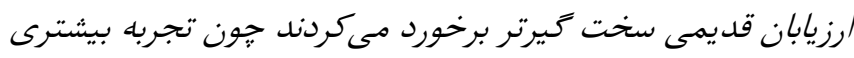

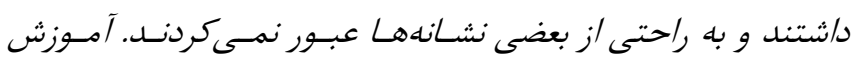

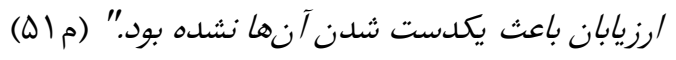

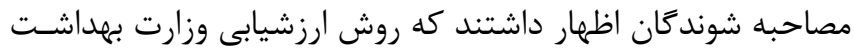

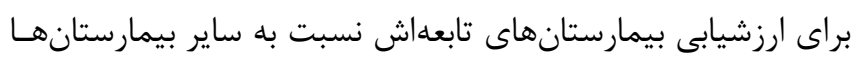

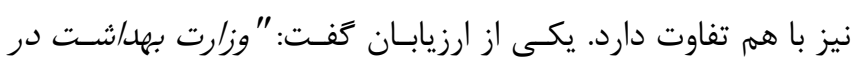

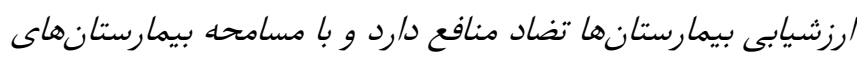

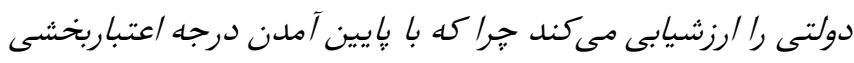

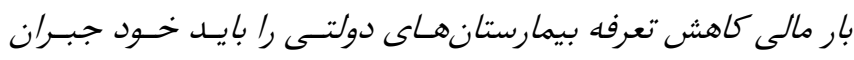

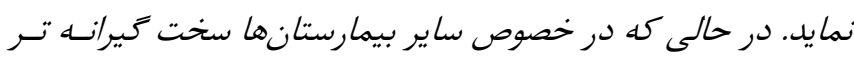

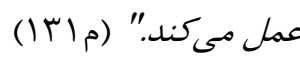

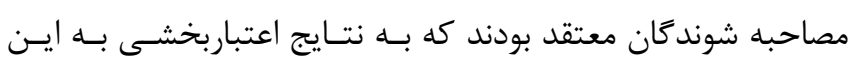

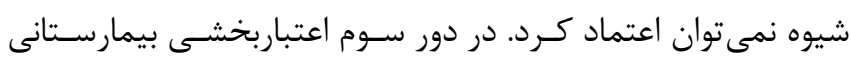

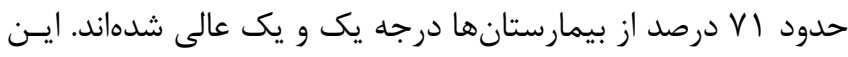

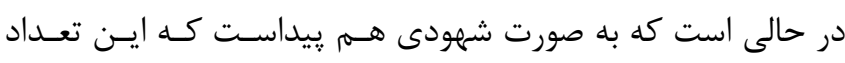

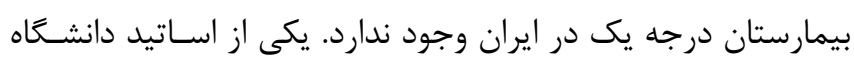

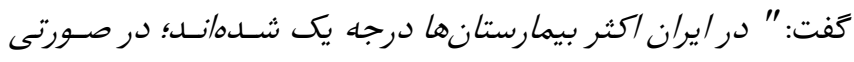

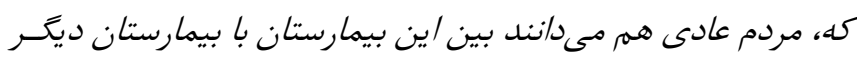

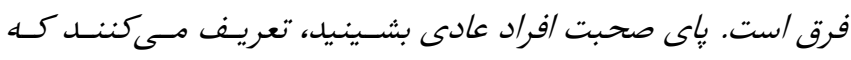

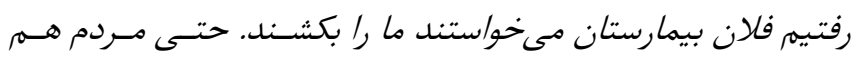

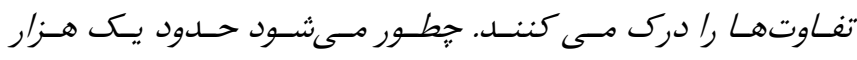

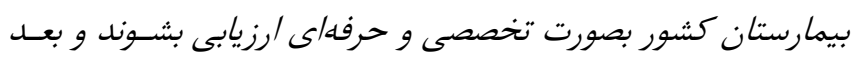

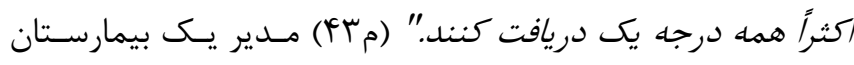

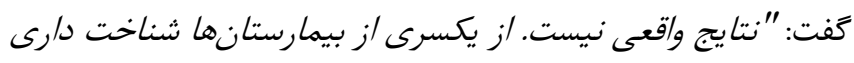

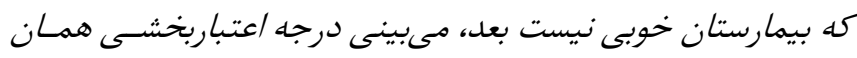

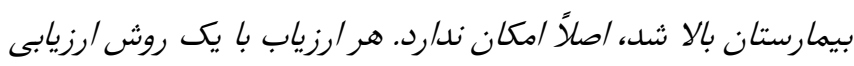

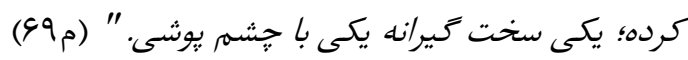

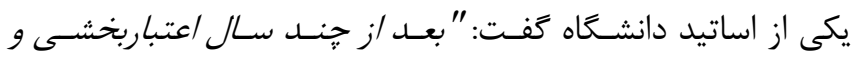

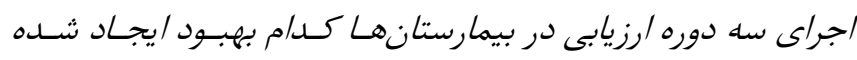


طول مدت اعتباربخشى: طول مدت انجام اعتباربخشى با توجـهـ بـهـ

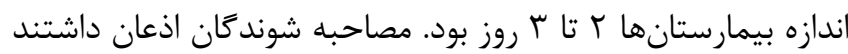

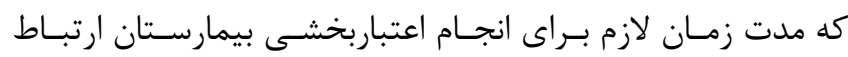

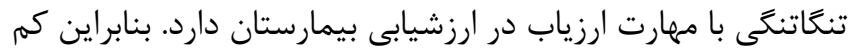

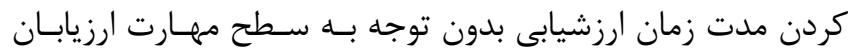

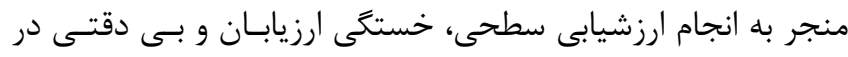

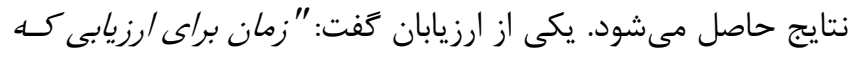

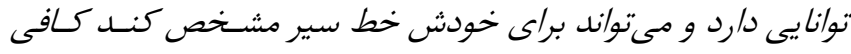

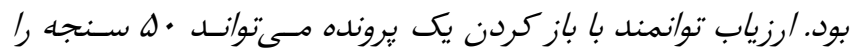

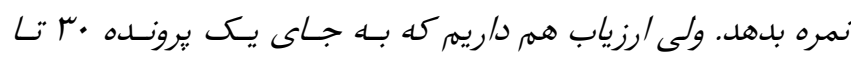

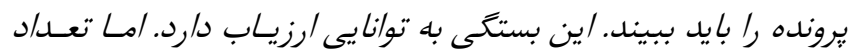

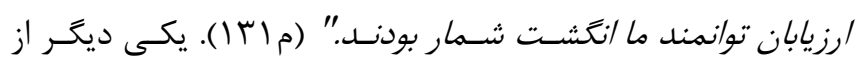

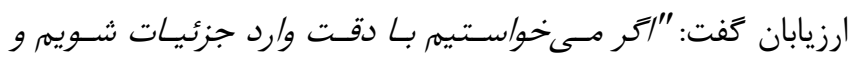

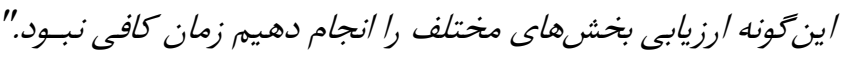

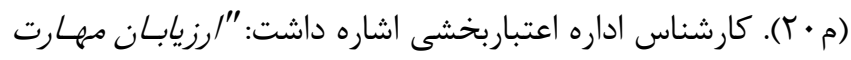

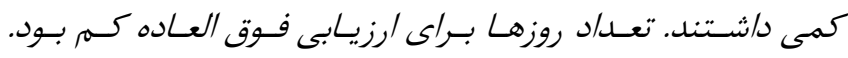

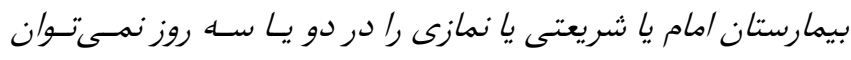

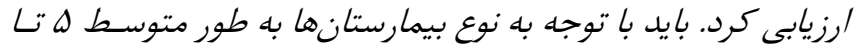

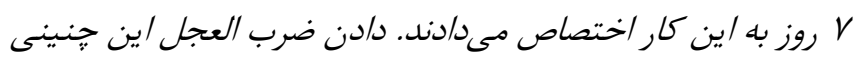

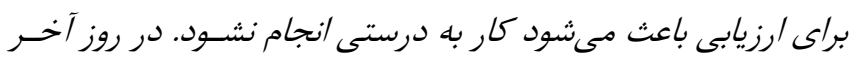

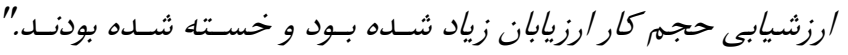

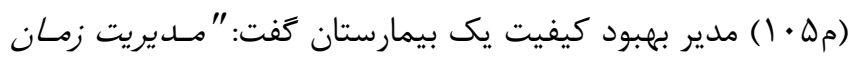

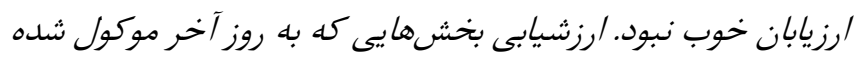

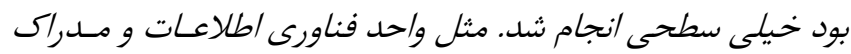

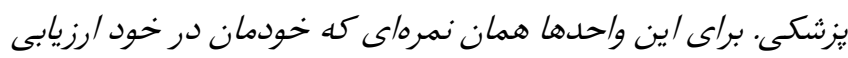

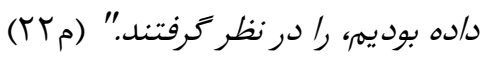

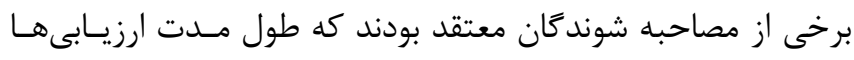

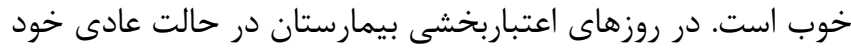

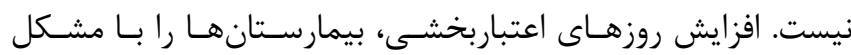

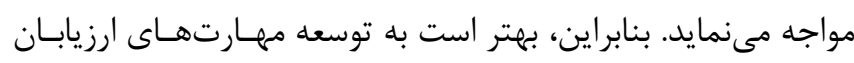

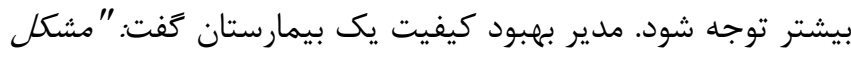

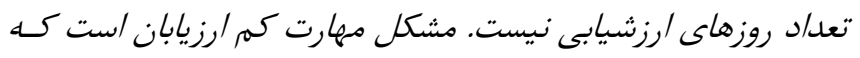

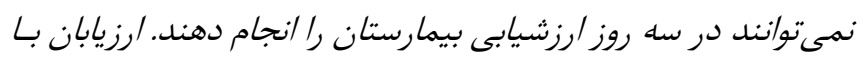

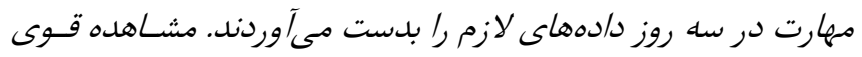

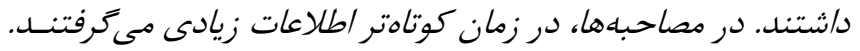

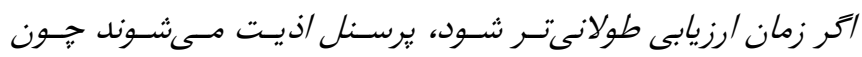

رويكرد /ستانداردها /ز بخشسى بـه كساركردى وجـود خواهـــ داشـت. بنابراين، رويكردى لازم/ست كه بيمار محور بوده و توجسه بـه /رائسه

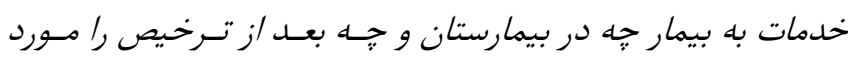
توجه و رزشيابي قرار دهد كه البتـه موفقيـت هـر روشسى كسه بكار

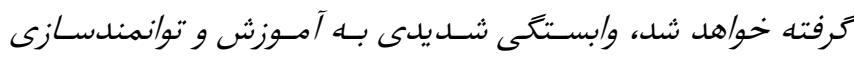

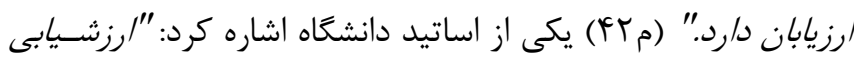

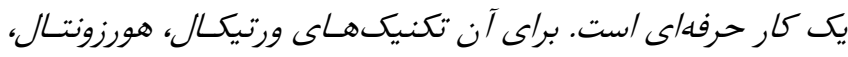

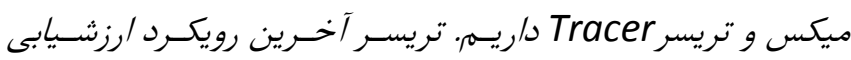

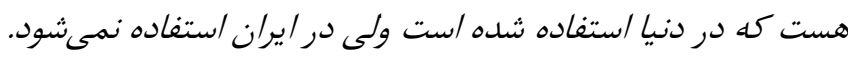

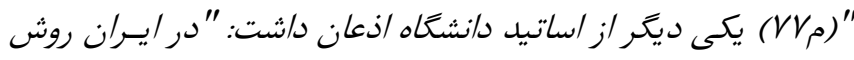

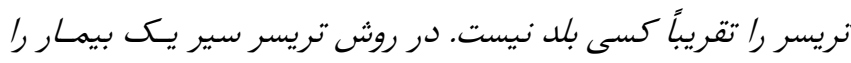

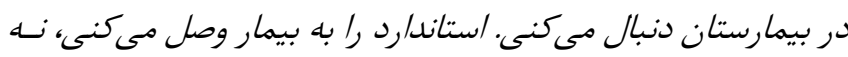

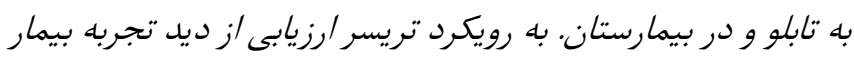

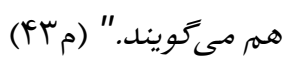

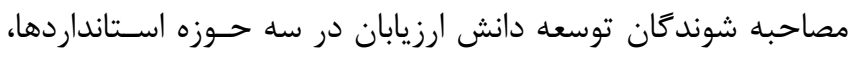

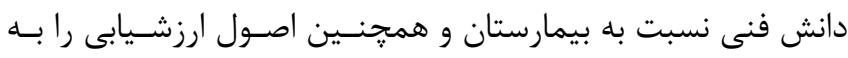

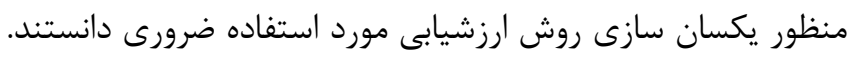

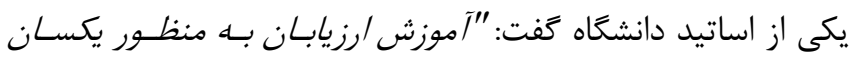

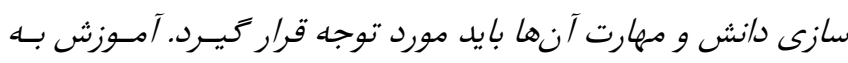

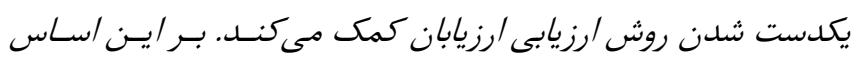

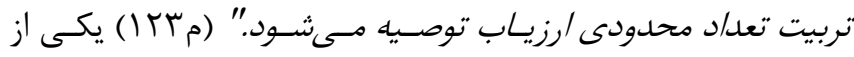

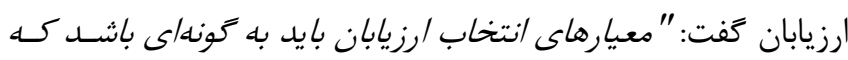

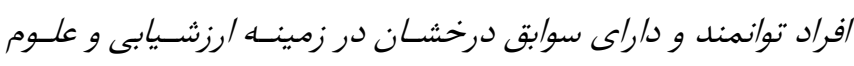

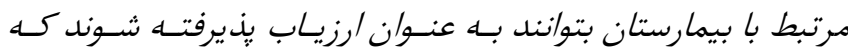

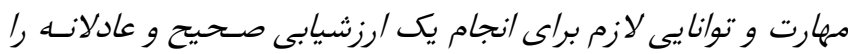

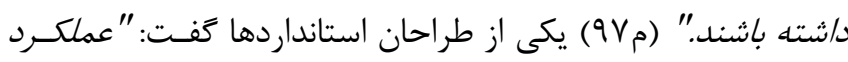

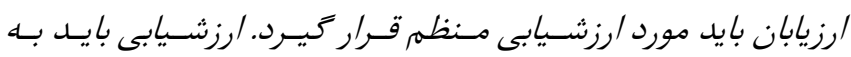

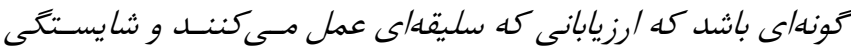

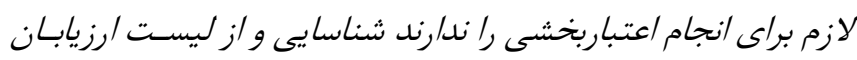

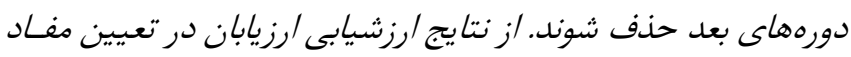

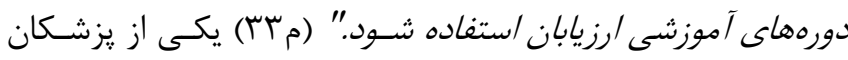

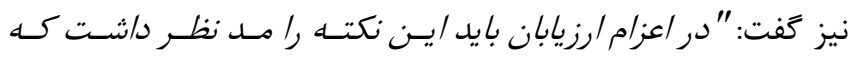

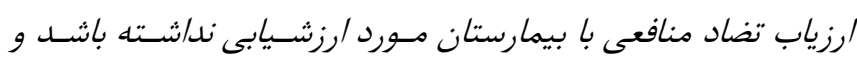

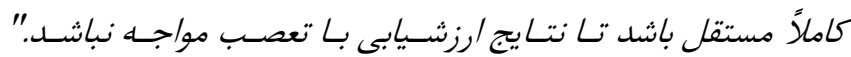


باشد كه بيمارستان /زكد/م قسمت نمره نخرفتـه /سـت. بيمارستان موظف باشد براى موارد عدم /نطباق برنامه عمليـاتى بنويســ و تسـيم

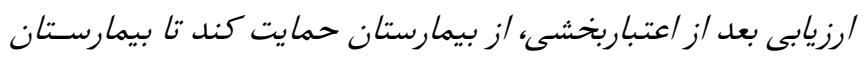

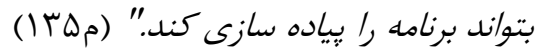

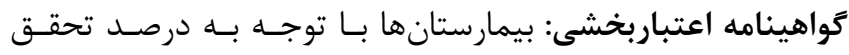

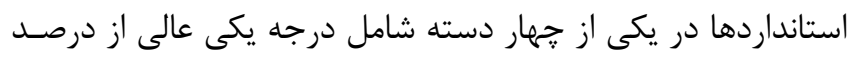

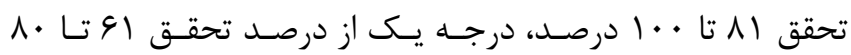

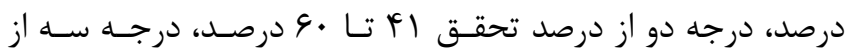

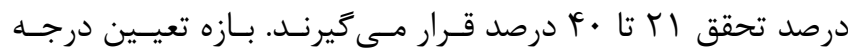

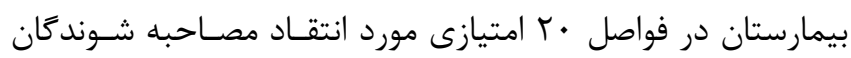
قرار داشت. مدير يكى بيمارستان كفت: /ين نوع درجهبندى /نَّيـزه

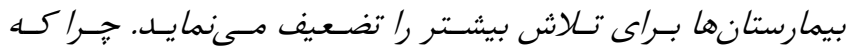

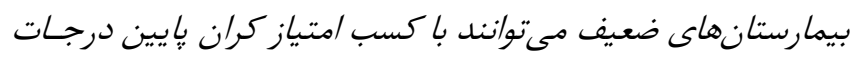
بالا، درآن تروه جاى داده شوند وقراركيرى بيمارستانهاى قوى و و ضعيف در يك كروه /نحيزه بيمارستانها براى تلاش بيشتر را /ز بين

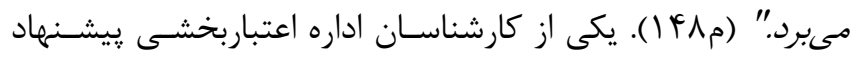
داد كه :" فاصله درجه بندىها حداقل براى دريافت درجسه يــ و و عالى كوزجكتر شود تا تفاوت بين بيمارستانها بهتر مورد توجه قـرار

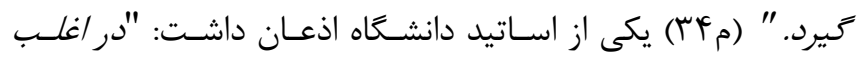

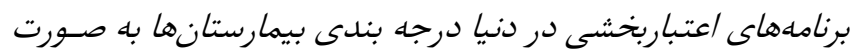

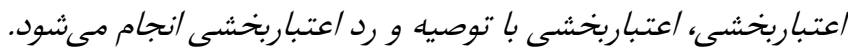

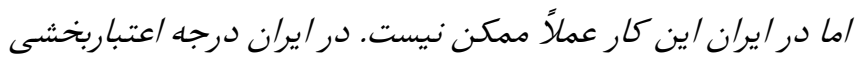

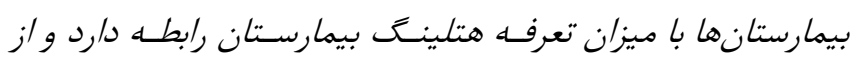

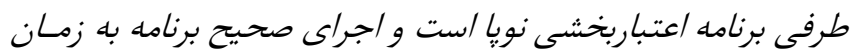

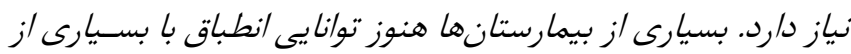

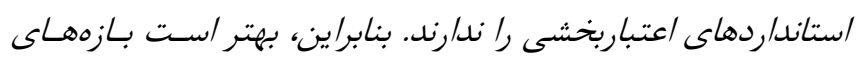

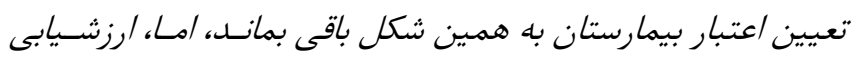

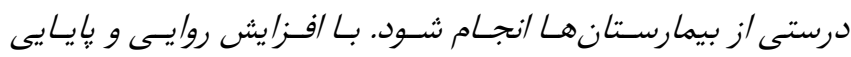

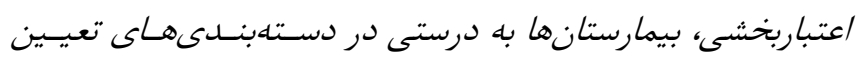
شله قرار مى حيرند." (مV (FV)

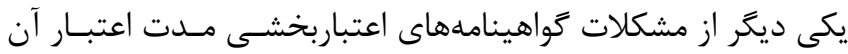

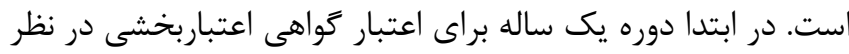

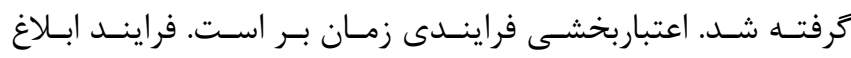

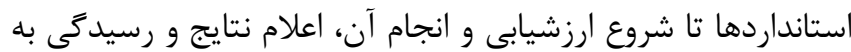

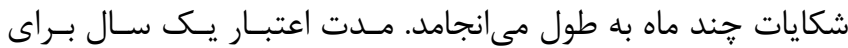

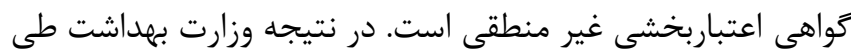

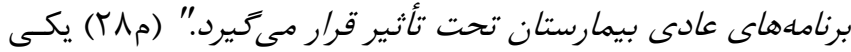

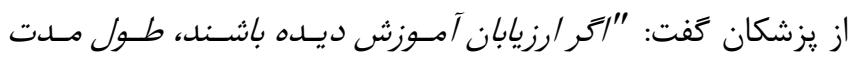
ارزشيابیىها خوب /ست." (م • IT) بازخورد: هدف از اعتباربخشى بهبود كيفيت و ايمنسى بيمـار اسـت.

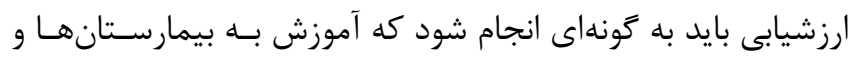

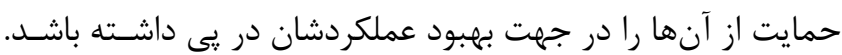

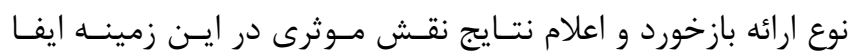
مى نمايد. بازخورد بايد به موقع بوده و به نحوى ارائه شود كـهـ تـأثير

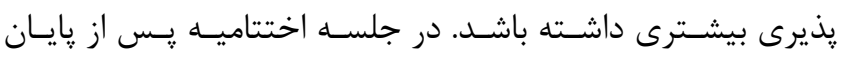

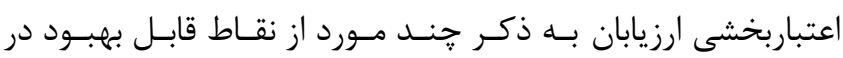
بيمارستان يرداختند. اما گزارش كتبى از نحوه عملكرد بيمارستانها

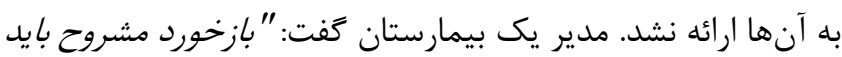

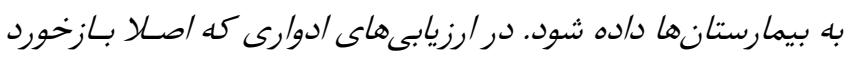
داده نمىشود. در واقع ما در فاصله دو دوره اعبتاربخشى نمى دئسانسيم

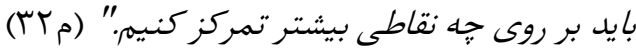

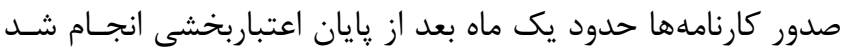
كه بصورت اعلام درصد تحقق استانداردها بود. مصاحبه شوند نحوه اعلام نتايج اعتباربخشى ابراز ناخرسندى كردنـد. متـرون يـك

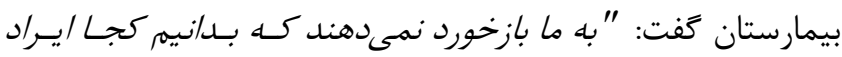

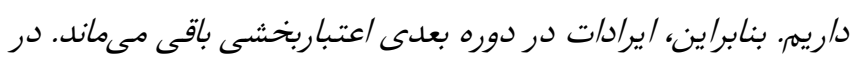
هر محور به طور كلى مى كويند مثنلا لها درصد تحقق داشته/يل، اما،

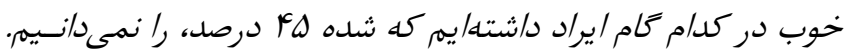

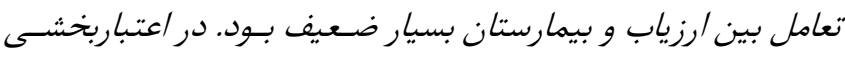

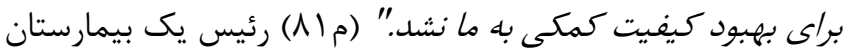

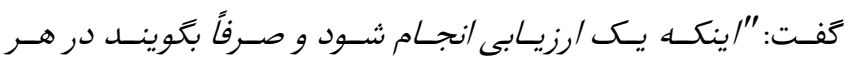

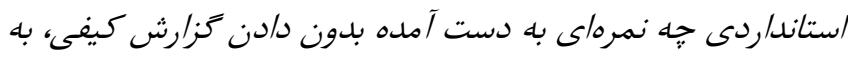
خودى خود باعث بهبود نمىشود. " مصاحبه شوندكَان توصيه مى كنند كه ارائه گَـزارش كتبـى از نقــاط

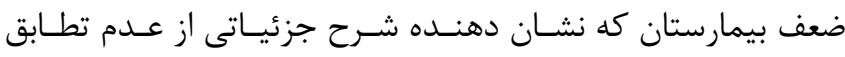
بيمارستان ها با عملكرد مطلوب است مورد توجه قرار زيـرد. يكـى از

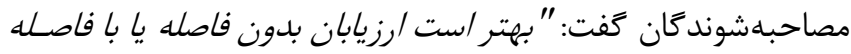

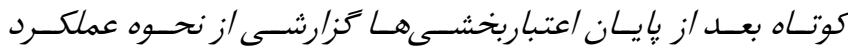

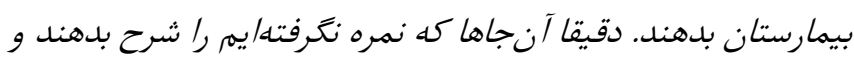

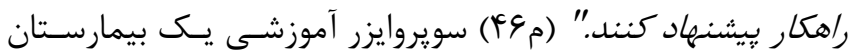

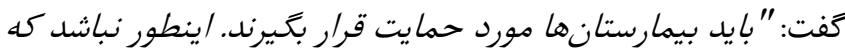

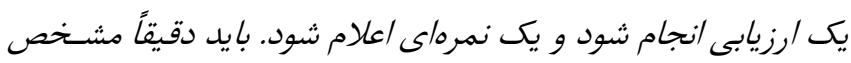




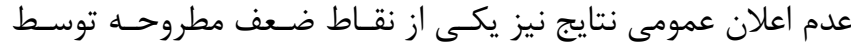

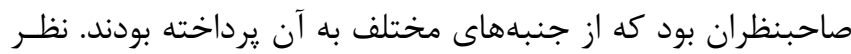

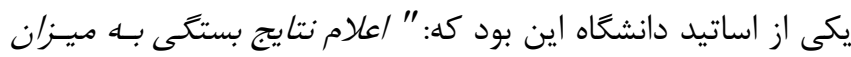

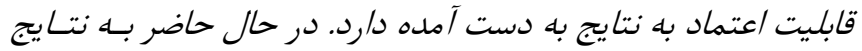

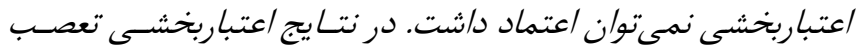

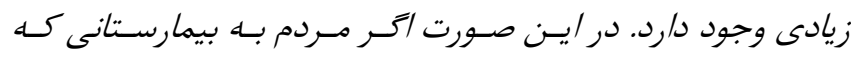

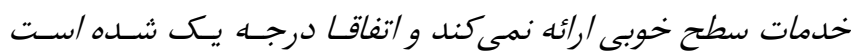

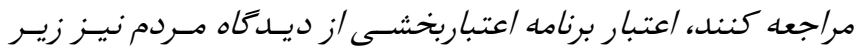

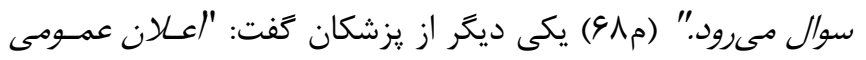

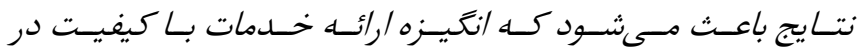

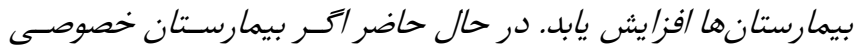

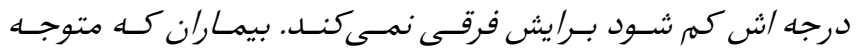

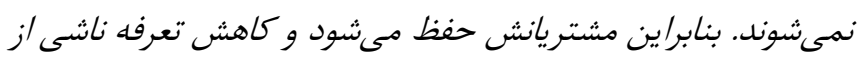

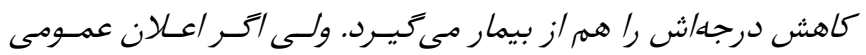

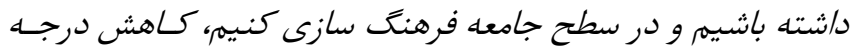

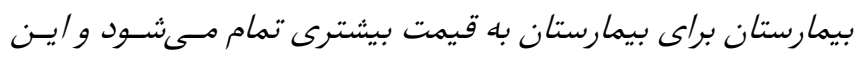

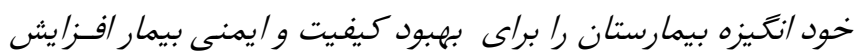

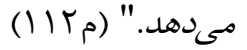

بخشنامهاى به بيمارستانها مدت اعتبار گواهىهاى صادر شده را به

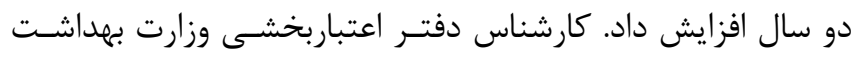

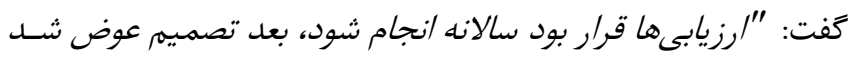
و مقرر شد دو سال يكبار اعتباربخشى انجام شود. متأسفانه در /يران

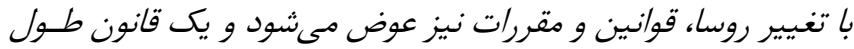

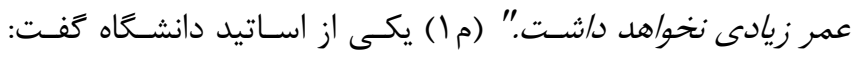

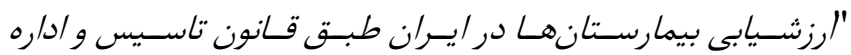

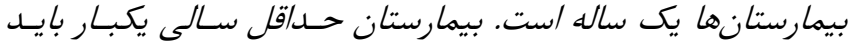

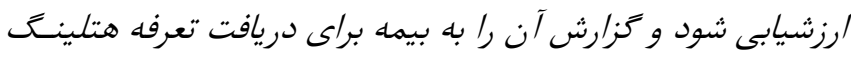

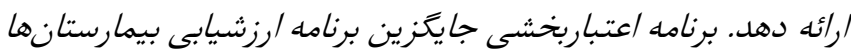
با همان شرايط شده /ست. بخش نامه اخير وزارت بهد/شت مبنى بـ بـر

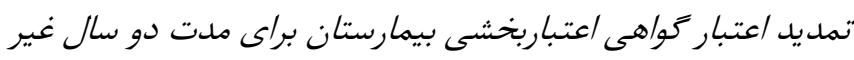

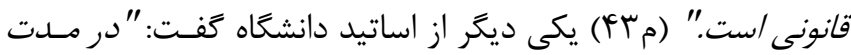

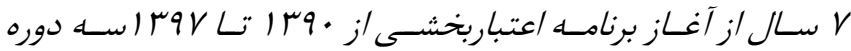

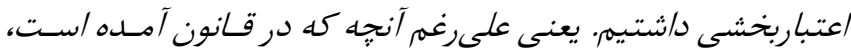

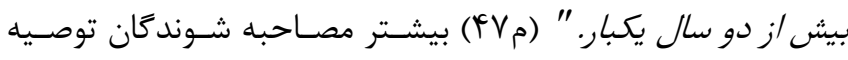

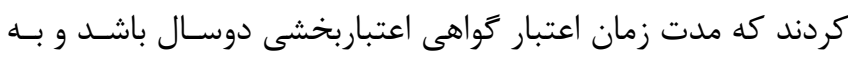

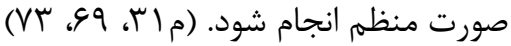

جدول ا: اطلاعات جمعيت شناختى شركت كنندكان در مصاحبه

\begin{tabular}{|c|c|c|c|c|c|}
\hline د مرصد & 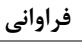 & متغير & د مرصد & 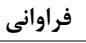 & متغير \\
\hline & & سمت & & & جنسيت \\
\hline 4 & 9 & كارشناسان اداره اعتباربخشى & rV/A & $\Delta V$ & 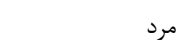 \\
\hline $9 / 9$ & $1 \cdot$ & اعضاء هيت علمى و اساتيد & $G T / r$ & 94 & 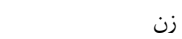 \\
\hline$r 1 / \Lambda$ & $4 \lambda$ & مديران ارشد، ميانى و عملياتى بيمارستان & & & \\
\hline $9 / 9$ & 10 & يزشكان بيمارستان & & & سن سن \\
\hline$r M / \Lambda$ & 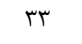 & كارشناسان بهبود كيفيت بيمارستان & $1 r / 9$ & T) & $r \Delta-r \cdot$ \\
\hline $1 r / 9$ & rI & ارزيابان اعتباربخشى & 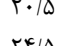 & $\begin{array}{ll}r 1 \\
r y\end{array}$ & rl-ra \\
\hline r & 4 & كارشناسان بيمه سلامت & $t r / Q$ & 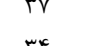 & res-r. \\
\hline \multirow[t]{4}{*}{4} & \multirow[t]{3}{*}{9} & \multirow{3}{*}{ طراحان استانداردهاى اعتباربخشى } & $T r / \Delta$ & re & $\mid+1-i \Delta$ \\
\hline & & & $9 / 9$ & 10 & $\Leftrightarrow \varphi-\Delta$. \\
\hline & & & N/9 & 14 & $\Delta 1-\Delta \Delta$ \\
\hline & & سابقه كار & & & تحصيلات \\
\hline$T F / \Delta$ & rv & كمتر از • ا سال & $19 / \pi$ & rq & كارشناسى \\
\hline rv & $\Delta \varphi$ & 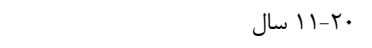 & er & 90 & كارشناسى ارشد \\
\hline$r q / 1$ & Fa & 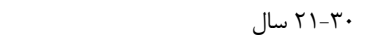 & rV/A & $\Delta V$ & دكترا \\
\hline \multirow[t]{2}{*}{ N/9 } & ir & 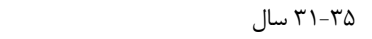 & & & \\
\hline & & سابقه اعتباربخشى & & & محل خدمت \\
\hline $10 / r$ & r & كمتر از ه سال & $r / \Gamma$ & $\Delta$ & 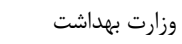 \\
\hline ET/F & $g f$ & 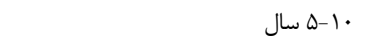 & $10 / 9$ & TF & دانشكاه علوم يزشكى \\
\hline$r \Lambda / \Delta$ & pr & 11-11 سال & Ve/A & 119 & بيمارستان \\
\hline $1 \% / 9$ & rI & 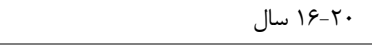 & r & 4 & سازمان بيمه \\
\hline
\end{tabular}


سال بيستم، شماره ششم، آذر -دى .. If

نشريه يروهشكده علوم بهداشتى جهاددانشكاهى

جدول r: جالشهاى اصلى و فرعى و راهكارهاى روش ارزشيابى اعتباربخشى بيمارستانى ايران

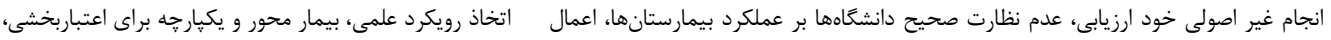

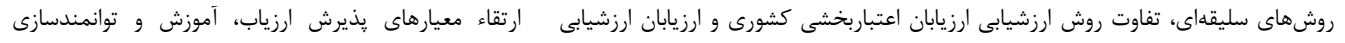

روش اعتباربخشى

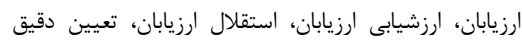

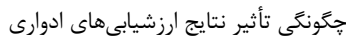

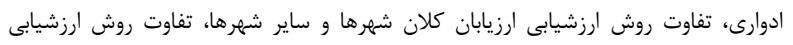

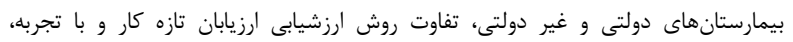

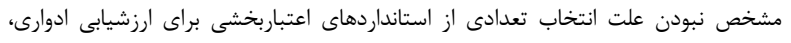

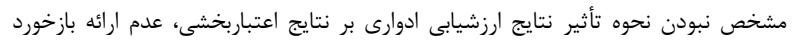

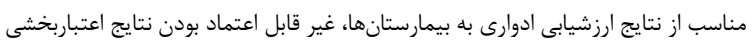

\begin{tabular}{|c|c|c|}
\hline توسعه دانش و مهارت ارزيابان & عدم مديريت صحيح زمان، انجام ارزشيابى سطحى، خستخى ارزيابان، افزايش بى دقتى & طول مدت اعتباربخشى \\
\hline 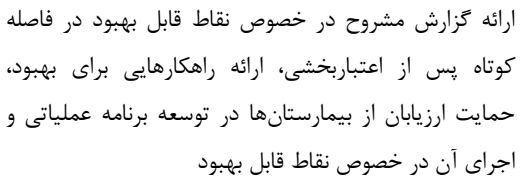 & 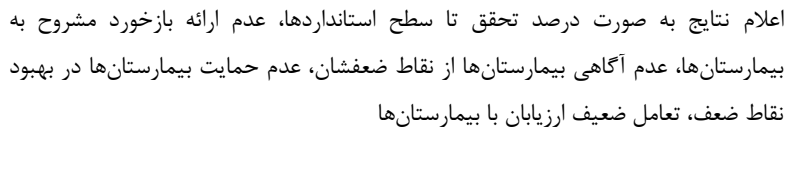 & 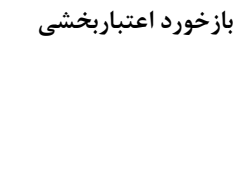 \\
\hline 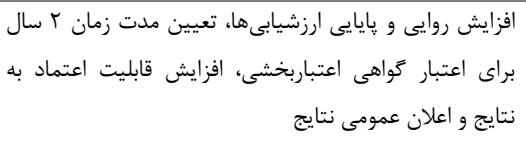 & 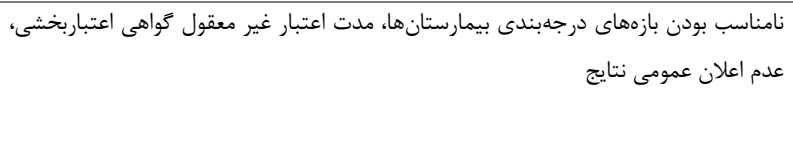 & كواهينامه اعتباربخشى \\
\hline
\end{tabular}

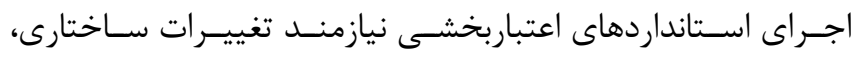

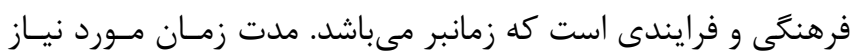

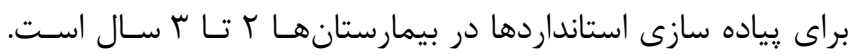

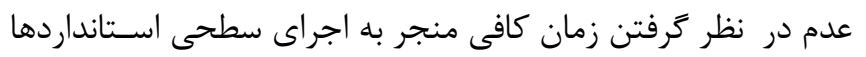

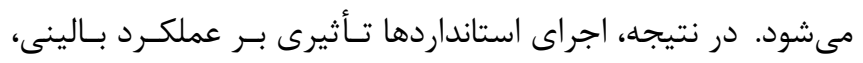
عملياتى و مالى بيمارستانها نخواهد داشت.

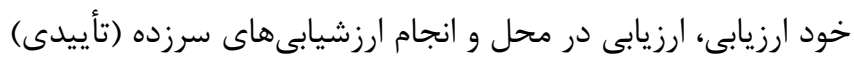

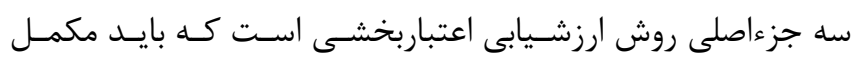

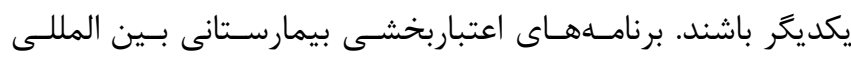

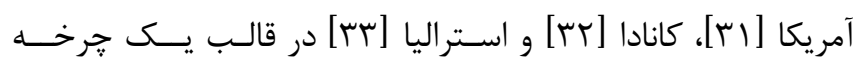

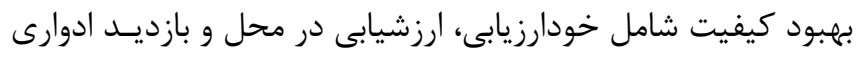

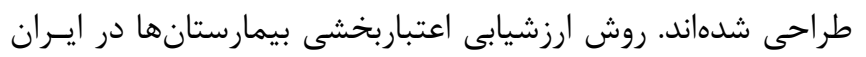

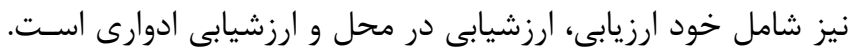

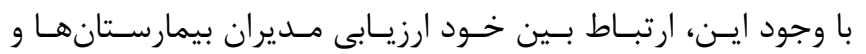

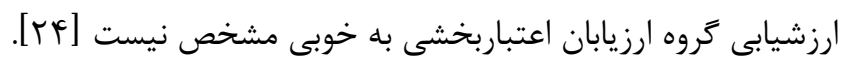

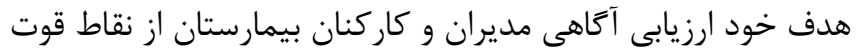
و ضعف بيمارستان و بكاركيرى اقدامات اصـلاحى اسـت. همجنــين،

\section{بحث و نتيجه گيرى}

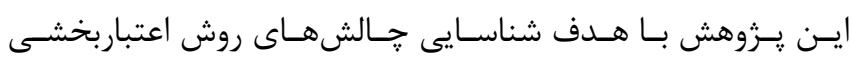

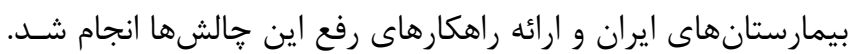

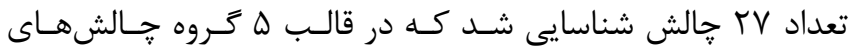

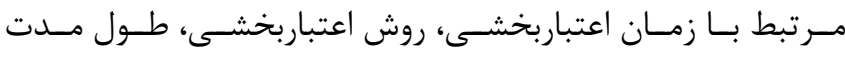

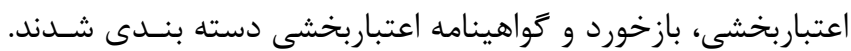

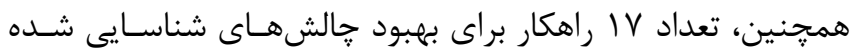

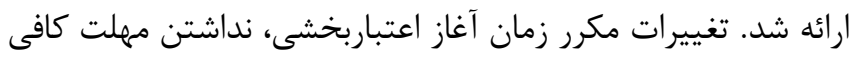

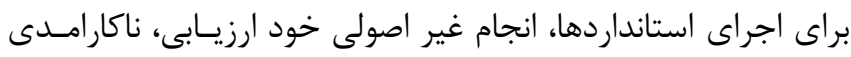

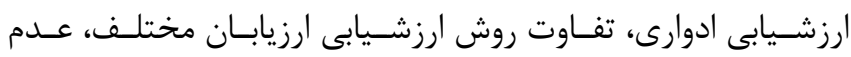

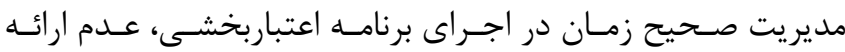

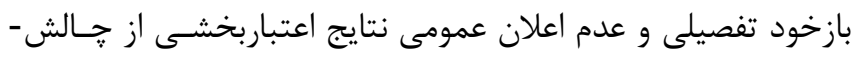

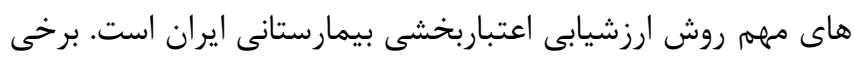

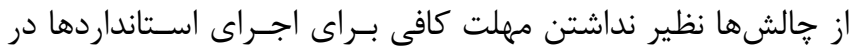

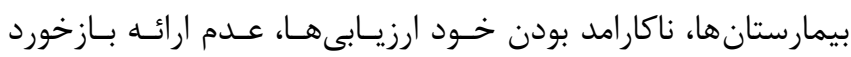

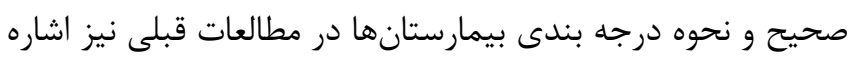

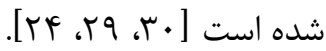


ارزشيابى ساختارها به مهارت كمترى نياز دارد. بنابراين، ارزيابان كم تجربه بيشتر به سنجش سـاختارها مسى يردازنـد. تعيسين معيارهـاى

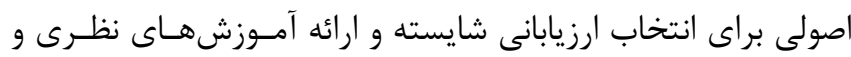

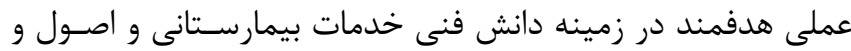

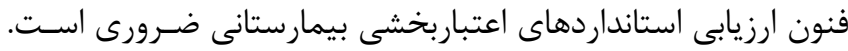

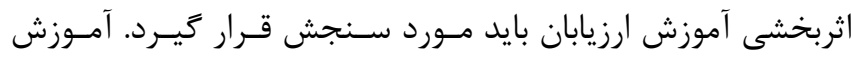
اثربخش به يكدست شدن روش ارزشيابى ارزيابان كمك مي كند.

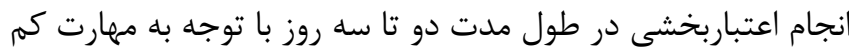
ارزيابان مورد انتقاد مصاحبه شوندكان قرار داشت. طول مدت فرات فرايند

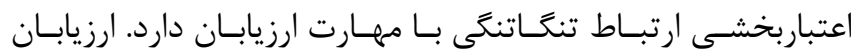

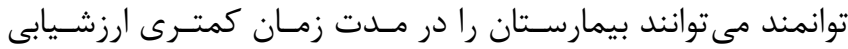

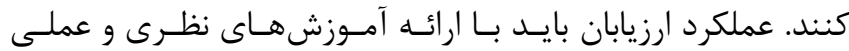

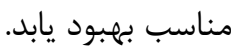

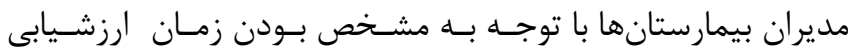

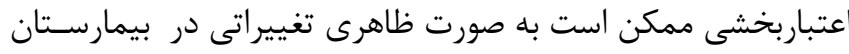

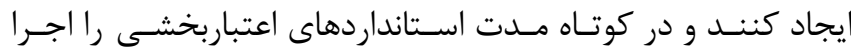

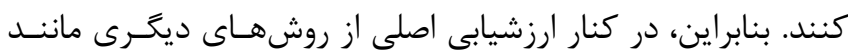

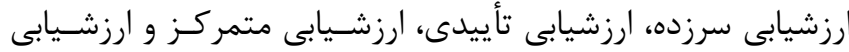

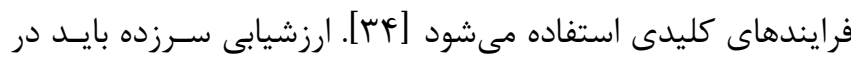

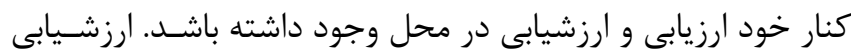

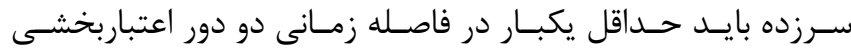
بيمارستان انجام شود. ارزشيابى سرزده بايد بر اساس اسـتانداردهاى

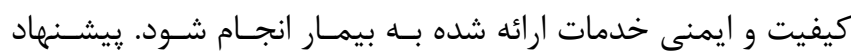

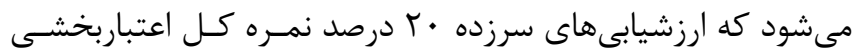

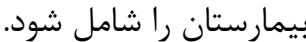

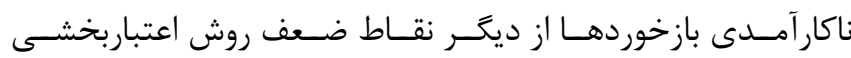

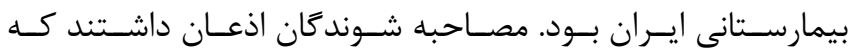

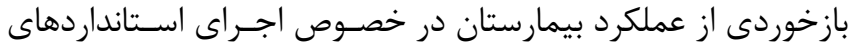

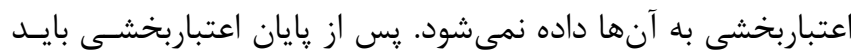

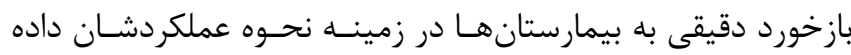

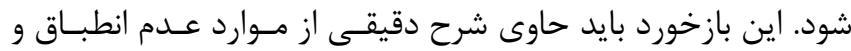

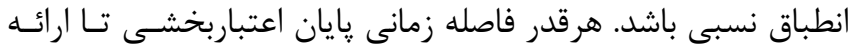

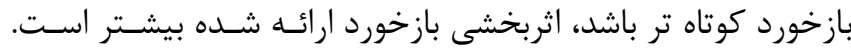

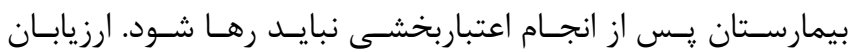

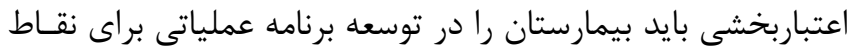

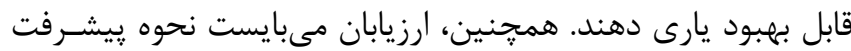

ارزيابان اعتباربخشى با مطالعـه نتـايج خـود ارزيـابى بيمارسـتانهـا مى توانند شناخت مقدماتى از بيمارستان به دسـت آورنــد و انتخــاب

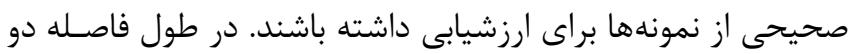

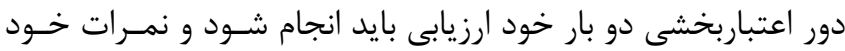

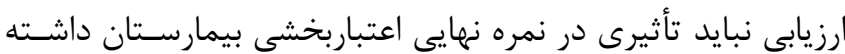

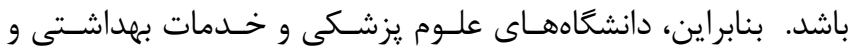

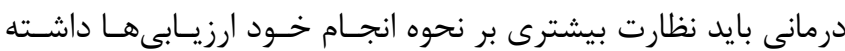
باشند تا از بروز خطاهاى احتمالى ممانعت به عمل آيد.

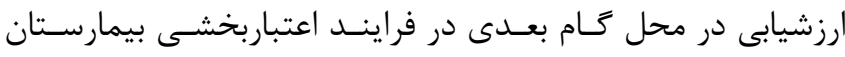

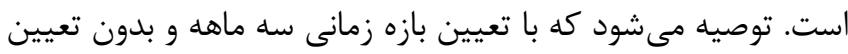

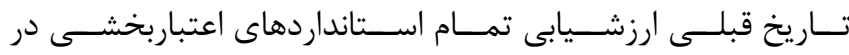

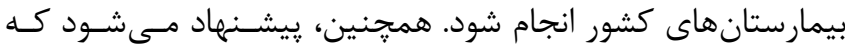

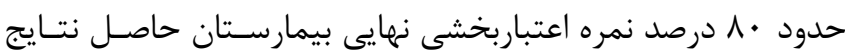
ارزشيابى در محل باشد. روش اعتباربخشى بايد از پايايى و روايى بـالايى برخـوردار باشـد تـا

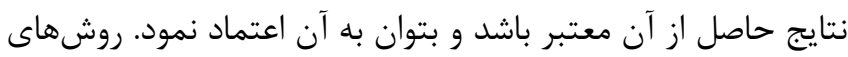

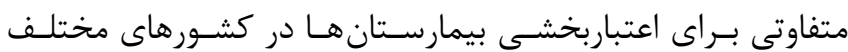

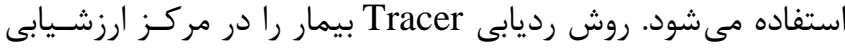

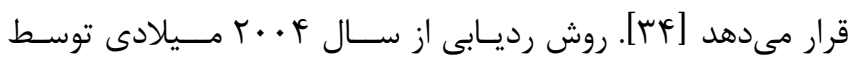

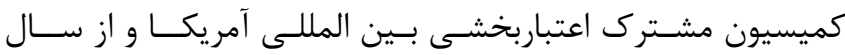

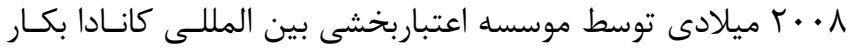
كرفته شده است. اين روش تصوير واقعىتر از عملكرد بيمارستانهـا

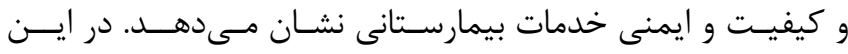

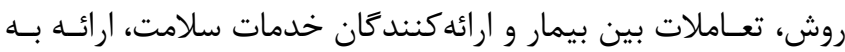

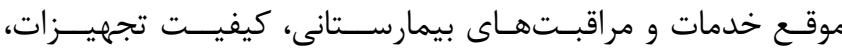

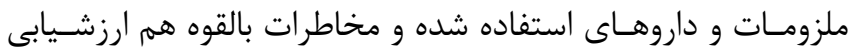
مسىشـوند. از فنـون مشـاهده، مصـاحبه، بحـث كروهـى متمركـز و و

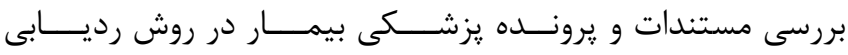

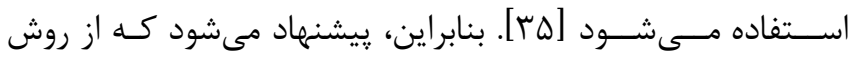
رديابى براى اعتباربخشى بيمارستانهاى ايران استفاده شود. ارزيابان

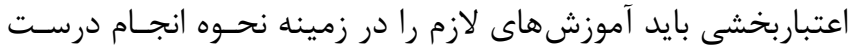
اين روش ارزشيابى دريافت دارند.

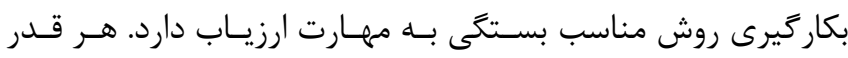
ارزياب توانمندى و مهارت بيشترى داشته باشـــ امكـان اسـتفاده از روشهاى بيمار محور بيشتر است. در اعتباربخشى اجزاى ساختارها،

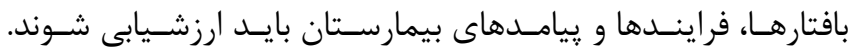


بهداشتى درمانى فرهنَ سازى شـود. توصسيه مسىشـود كـهـ نتـايج

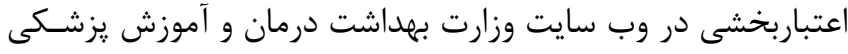

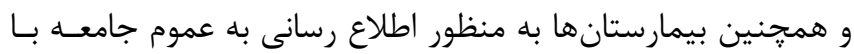
هدف توسعه فرهنَ ايمنى و كيفيت در دو بعد عرضه و تقاضا براى خدمات سلامت منتشر شود. اعلان عمومى نتايج اعتباربخشى منجر

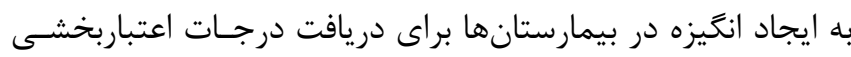

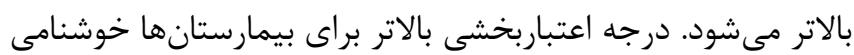

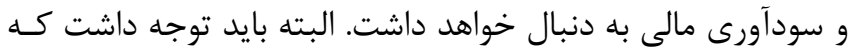

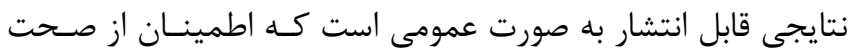

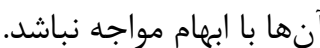
در اين يزوهش جالشهاى روش ارزشيابى اعتباربخشى بيمارستانى إنى

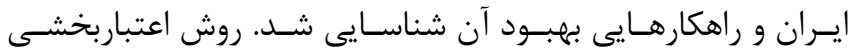

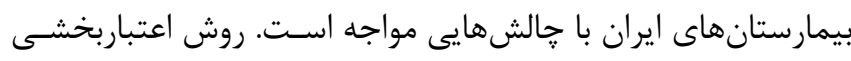

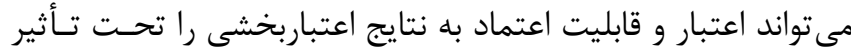

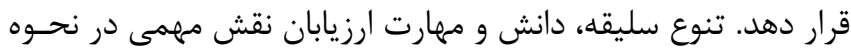

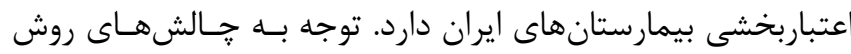

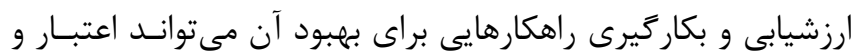

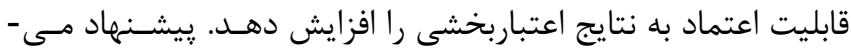
شود كه مطالعات مشابهى در زمينه جالشهاى ارزيابان اعتباربخشى إنى براى تقويت برنامه اعتباربخشى بيمارستانى ايران انجام گيرد.

\section{سهم نويسند}

على محمد مصدق راد: طراحى يـرَوهش، تحليـل دادهـــا و نخــارش مقاله ابراهيم جعفرى يويان: طراحى يـروزهش، تحليـل دادههـا و نعَـارش مقاله فاطمه غضنفرى: طراحى يزوهش، جمع آورى دادهها، تحليل دادهها

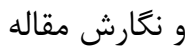

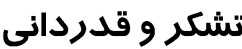

اين مقاله حاصل بخشى از بايان نامه دكترى با عنوان توسـعه مــل

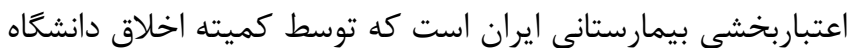

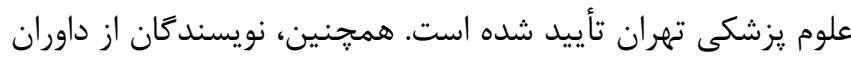

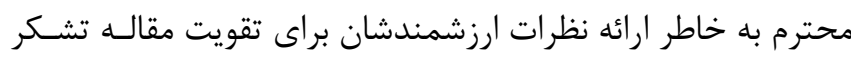

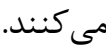

بيمارستان در برنامههاى عملياتى را رصد كنند و به آنها ييشنهادات

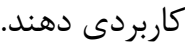

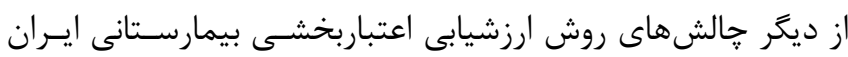

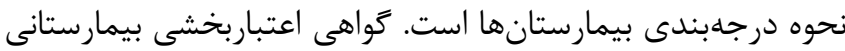

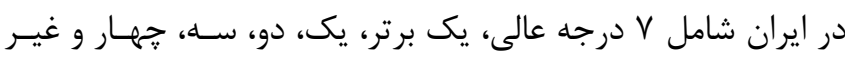

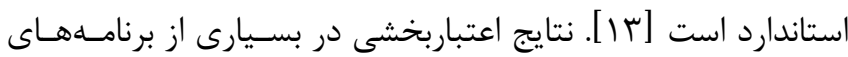

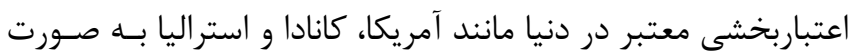

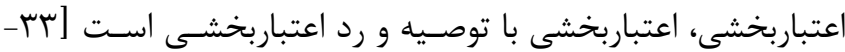

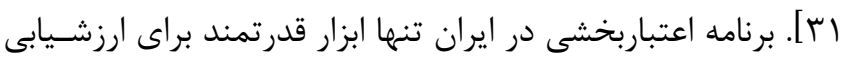

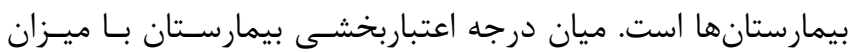

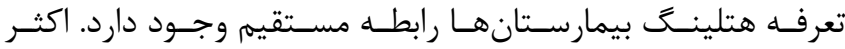

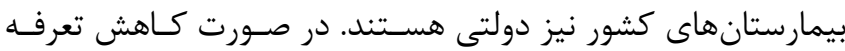

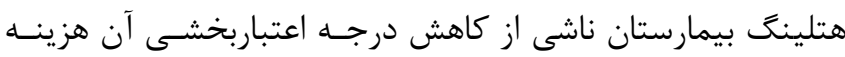
سنگينى به بيمارستان تحميل مى شود. بنابراين، مدل مورد استفاده

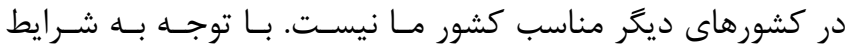

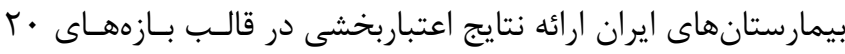
تايى شامل كواهىنامههاى اعتباربخشى درجه عالى (اجـراى . . 1 -

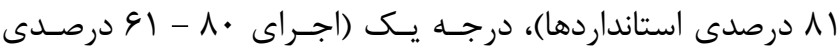

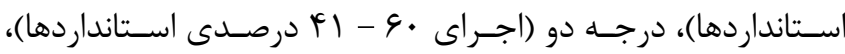

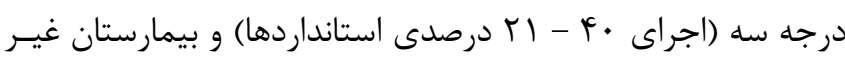
استاندارد (اجراى كمتر از • ب درصد استانداردها) مناسب است.

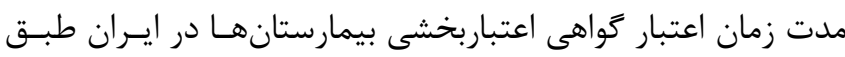

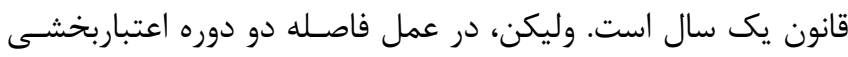

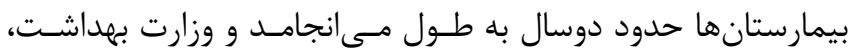

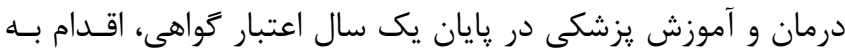

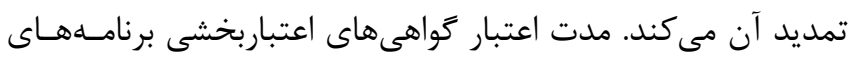

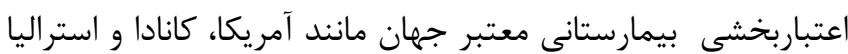

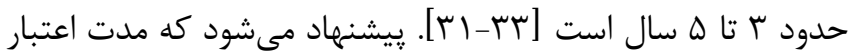

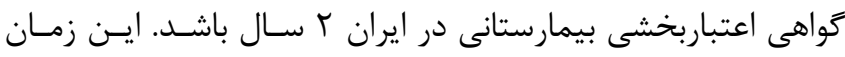

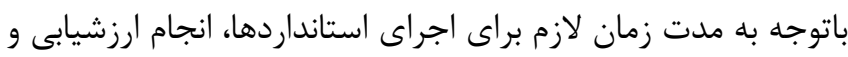

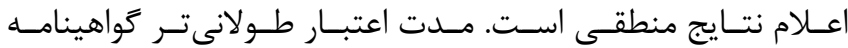

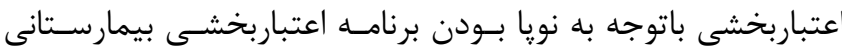
ايران توصيه نمىشود.

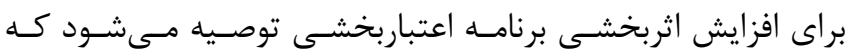

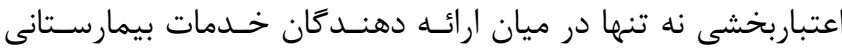

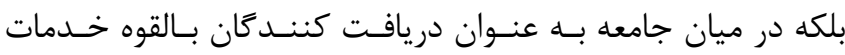




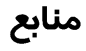

1. Mosadeghrad AM. Essentials of healthcare organization and management $.1^{\text {st }}$ Edition, Tehran: Dibagran; 2015

2. Mosadeghrad AM. Hospital accreditation: The good, the bad, and the ugly, International Journal of Healthcare Management. 2020:1-5.

3. Mosadeghrad AM. Comments on Iran hospital accreditation System.Iranian Journal of Public Health 2016; 45: 837-842

4. Mosadeghrad AM. Iran hospital accreditation: Future directions $.1^{\text {st }}$ Edition in J. Braithwaite, et al., (Eds.) Health Care Systems: Future Predictions for Global Care, Taylor \& Francis 2018: 285-291

5. Alkhenizan A, Shaw C. Impact of accreditation on the quality of healthcare services: a systematic review of the literature. Annals of Saudi Medicine 2011; 31: 407-416

6. Lutfiyya MN, Sikka A, Mehta S,et al. Comparison of US accreditedand non-accredited rural critical access hospitals. . International Journal for Quality in Health Care 2009;21:112-8

7. Schmaltz SP, Williams SC, Chassin MR,et al. Hospital performance trends on national quality measures and the association with Joint Commission accreditation. Journal of Hospital Medcine 2011;6:454-61

8. Halasa YA, Zeng W, Chappy E,et al. Value and impact of international hospital accreditation: a case study from Jordan. Eastern Mediterrian Health Journal 2015;21:90-9

9. Yildız MS, Öztürk Z, Topal M,et al. Effect of accreditation and certification on the quality management system: analysis based on Turkish hospitals.International Journal of Health Planning and Management 2019;34:e1675-87

10. Hadley TR, McGurrin MC. Accreditation, certification, and thequality of care in state hospitals. Psychiatric Services1988;39:707-10

11. Schmaltz SP, Williams SC, Chassin MR,et al. Hospital performance trendson national quality measures and the association with Joint Commission accreditation.Journal of Hospital Medcine 2011;6:454-61

12. Mosadeghrad A M, Akbari-sari A, Yousefinezhadi T. Evaluation of hospital accreditation standards. Razi Journal of Medical Sciences 2017; 23: 43-54 [In Pesian]

13. Iran Health Ministry, Implementation guideline of the $4^{\text {th }}$ hospital accreditation survey. Ministry of
Health.

Available

at:

http://treatment.sbmu.ac.ir/uploads/etebarbakhshi_stan dard_book_98.pdf 2019 [In Pesian]

14. Reisi N, Raeissi P, Sokhanvar M, Kakemam E. The impact of accreditation on nurses' perceptions of quality of care in Iran and its barriers and facilitators. The International journal of Health Planning and Management 2019; 34: 230-40

15. Moradi R, Nemati A, Bahmanziari N, Shokri A, Mohammadi M. The impact of accreditation on services of Isfahan University hospitals. Health Care Management Journal 2015; 6: 67-76

16. Mosadeghrad A M, Ghazanfari F. Iran hospital accreditation governance: Challenges and solutions. Payavard 2020; 14:311-332 [In Pesian]

17. Ghazanfari F, Mosadeghrad AM, Jaafari Pooyan E, Mobaraki H. Iran Hospital Accreditation Standard: challenges and solution. International Journal of Health Planning and Management 2021; 36: 1-18

18. Pourreza A, Mosadeghrad AM, Zoleikani P. The impact of accreditation on the performance of hospital emergency departments. Journal of Health Based Research 2017; 3: 277-95

19. Jaafaripooyan E, Sharifi T, Yekani Nejad MS, Esmaeili S. Relationship between Accreditation Rank and Technical Efficiency of Hospitals Affiliated to Tehran University of Medical Sciences. Journal of Hospital 2018; 17: 49-57 [In Pesian]

20. Fotuhi MA, Khoshgoftar A, Bakhshande A, Karami Q, Rasti M. Evaluation of Viewpoint of Executive Management Team of Hospitals of Qom Province in Terms of the Third Generation of Hospital Accreditation Standards. Qom University Medical Sciences Journal 2018;12: 62-70 [In Pesian]

21. Yarmohammadian M, Shokri A, Bahmanziari N, Kordi K. The blind spots on Accreditation program. Journal of Health System Research 2013; 9: 1158-66 22. Mohebbifar R, Rafiei S, Asl AM, Ranjbar M, Khodayvandi M. Association between hospital accreditation and patient satisfaction: a survey in the western province of Iran. Bangladesh Journal of Medical Science 2017; 16: 77-84. [In Pesian]

23. Yousefinezhadi T, Mosadeghrad AM, Hinchcliff R, Akbari-Sari A. Evaluation results of national hospital accreditation program in Iran: The view of hospital managers. Journal of Healthcare Quality Research 2020; 35: 12-18 
24. Mosadeghrad AM, Nabizade Z. Evaluation of Iranian hospital accreditation system. Payesh 2018; 17: 617-629 [In Pesian]

25. Guba EG, Lincoln YS. Competing paradigms in qualitative research. Handbook of Qualitative Research. $1^{\text {st }}$ Edition, CA: Sage: Uk, 1994; 105-117

26. Husserl E. Phenomenology and the foundations of the sciences. Germany: Springer Science \& Business Media 2001: 108

27. Maggs-Rapport F. Combining methodological approaches in research: Ethnography and interpretive phenomenology. Journal of Advanced Nursing 2000; 31: $219-25$

28. Braun V, Clarke V. Using thematic analysis in psychology. Qualitative research in psychology. Qualitative Research in Psychology 2006; 3: 77-101

29. Mosadeghrad AM, Shakibaei E. Hospital accreditation implementation prerequisites. Journal of Hospital 2017; 16: 43-56 [In Pesian]

30. Nekoei-Moghadam M, Amiresmaili M, Iranemansh M, Iranmanesh M. Hospital accreditation in Iran: A qualitative case study of Kerman hospitals, International Journal of Health Planning and Management 2018;33: 1-8
31. Joint Commission International Accreditation Hospital. Survey Process Guide, $4^{\text {th }}$ Edition. Joint Commission International: USA, 2013

32. Canada accreditation, Health Care Accreditation Process. Available from: https://accreditation.ca/. Retrieved July 5, 202040

33. Australian Council on Healthcare Standards. Australian Council on Healthcare Standards International. Available at https://www.achs.org.au/Retrieved June 27, 2020.

34. Bohigas L1, Brooks T, Donahue T, Donaldson B, Heidemann E, Shaw C,et al. A comparative analysis of surveyors from six hospital accreditation programmes and a consideration of the related management issues.International Journal for Quality in Health Care1998;10:7-13

35. Meireles VC, Labegalini CM, Baldissera VD. Tracer Methodology and the quality of care: integrative literature review. Revista Gaucha de Enfermagem 2019;40: e20180142

36. Introduction to DDKM. Available at :httPs://www.ikas.dk/den-danske-kvalitetsmodel/ddkm-inenglish/introduction-to-ddkm.2021 